\title{
Sociologists in Themselves, Sociologists for Themselves
}

The Sociology of Art and Culture at Association française de sociologie Congresses (2004-2013)

Sociologues en soi, sociologues pour soi. La sociologie de l'art et de la culture aux congrès de l'Association française de sociologie (2004-2013)

Sociologías en sí, sociólogo.a.s por sí. La sociología del arte y la cultura en los congresos de la Asociación francesa de sociología (2004-2013)

\section{Géraldine Bois and Adrien Thibault}

Translator. Jean-Yves Bart

\section{(2) OpenEdition}

\section{Electronic version}

URL: http://journals.openedition.org/bssg/285

DOI: $10.4000 /$ bssg.285

ISSN: 2490-9424

\section{Publisher}

Presses universitaires de Vincennes

\section{Electronic reference}

Géraldine Bois and Adrien Thibault, "Sociologists in Themselves, Sociologists for Themselves", Biens Symboliques / Symbolic Goods [Online], 3 | 2018, Online since 15 October 2018, connection on 04 March 2021. URL: http://journals.openedition.org/bssg/285 ; DOI: https://doi.org/10.4000/bssg.285 


\section{Sociologues en soi, sociologues} pour soi*

La sociologie de l'art et de la culture aux congrès de l'Association française de sociologie (2004-2013)
Sociologists in Themselves, Sociologists for Themselves*

The Sociology of Art and Culture at Association française de sociologie Congresses (2004-2013)

\author{
Géraldine Bois | Adrien Thibault \\ traduction | translation \\ Jean-Yves Bart
} «L'effet de la spécialisation [...] tend sans cesse à réduire l'univers des
concurrents par la division en sous-champs de plus en plus étroitement
spécifiés » (Bourdieu $1976: 99)$

La sociologie de l'art et de la culture ${ }^{1}$, reconnue comme spécialité en France depuis au moins une trentaine d'années (Moulin 1999),

* Cet article trouve son origine dans un premier travail réalisé pour le colloque " La "sociologie des arts et de la culture" et ses frontières. Esquisse pour une auto-analyse » (6-7 novembre 2014). Outre les deux auteur.e.s, trois autres membres du bureau du RT14 s'étaient alors prêtées au jeu de l'objectivation du réseau qu'elles animaient : Annabelle Boissier, Florence Eloy et Séverine Sofio. Même si la recherche s'est poursuivie sans elles, celle-ci est donc redevable des réflexions collectives de départ, fortement nourries par un travail quantitatif sur la revue Sociologie de l'Art-OPuS (Sofio 2013). Nous remercions également le comité de rédaction de Biens symboliques / Symbolic Goods, et plus particulièrement Frédéric Chateigner et Jérémy Sinigaglia pour leur relecture critique de versions préalables de ce texte, ainsi que Jean-Yves Bart pour sa traduction anglaise.

1 Nous retenons l'appellation la plus large et la plus neutre historiquement de « sociologie de l'art et de la culture », sans ignorer les débats autour de la
"The effect of specialization [...] tends to reduce the universe of competitors by dividing it into more and more narrowly specified fields" (Bourdieu 1976: 99).

The sociology of art and culture ${ }^{1}$ has been recognized as a speciality in France for at least thirty years (Moulin 1999). But is 
est-elle, comme le suggère l'hypothèse bourdieusienne, un souschamp de la sociologie - c'est-à-dire un espace social structuré de positions antagonistes disposant d'une relative autonomie (avec ses enjeux propres, son personnel, son capital spécifique, ses droits d'entrée, sa propre hiérarchie, etc.) ?

Une propriété nécessaire quoique non suffisante d'un champ, et par extension d'un sous-champ, est d'être constitué d'individus objectivement engagés dans une même activité sociale et liés entre eux, jusqu'à partager un ensemble de croyances et d'intérêts et jusqu'à s'investir dans des enjeux spécifiques ${ }^{2}$. Autrement dit, si on accepte de transposer les concepts de classe en soi et de classe pour soi inspirés de la théorie marxiste ${ }^{3}$, un champ se caractérise par l'existence d'une population de professionnel-le.s à la fois en soi et pour soi, c'est-à-dire à la fois objectivement et subjectivement proches entre eux·elles et éloigné·e.s d'autres populations de professionnel-le.s. Selon cette conceptualisation, on pourra étayer l'hypothèse de l'existence d'un sous-champ de la sociologie de l'art

mise au pluriel des termes « art » et « culture ». Quant au choix de distinguer « art » de « culture », il a vocation à clarifier le terrain dont il est question et à contourner le dilemme que ne manquerait pas de faire naître le choix de subsumer cette réalité sous un seul des deux vocables.

2 « [L]'investissement spécifique dans les enjeux [...] est à la fois la condition et le produit de l'appartenance à un champ » (Bourdieu 2009 [1981] : 119).

3 Ce couple conceptuel a été formulé par ses exégètes et non par Marx lui-même, qui identifie plutôt une « classe vis-à-vis du capital » et une " classe pour elle-même » (Andrew 1983) dans Misère de la philosophie (Marx 1847 : 176). Marx distingue en outre la classe au sens de «masse énorme dont les membres vivent tous dans la même situation » de la classe au sens d'ensemble de membres « unis les uns aux autres par des rapports variés » (Marx 1969 [1852] : 126). En soi et pour soi ne sont pas accordés en genre et en nombre, conformément à l'usage lorsqu'il est question des classes sociales (par ex., Chauvel 2001 : 317). Cette transposition nous a été initialement suggérée par Samuel Coavoux, contributeur du présent dossier. Qu'il en soit ici remercié. it, as Bourdieu's hypothesis suggests, a subfield of sociologyin the sense of a structured social space with opposing positions and a relative degree of autonomy (with its own stakes, personnel, specific capital, costs of entry, hierarchy, etc.)?

A necessary-albeit insufficient-property of a field, and by extension of a subfield, is that it is made up of individuals who objectively partake in the same social activity and share a bond, to the extent that they have a set of beliefs and interests in common and may become invested in specific issues ${ }^{2}$. In other words, if we transpose the concepts of "class in itself" and "class for itself" inspired by Marxist theory ${ }^{3}$, a field is characterized by the existence of a population of professionals both in themselves and for themselves; i.e., both objectively and subjectively close to each other and more distant from other populations of professionals. Under this approach, the hypothesis of the existence of a subfield of the sociology of art and culture will be proven if we manage to demonstrate that there is in fact a population of sociologists of art and culture in themselves and for themselves, which is distinct

the use of the terms "art" and "culture" in the plural. We chose to make a distinction between "art" and "culture" in order to clarify our field of inquiry and avoid the dilemma that using either of them to refer to the two would create.

2 "Specific investment in the stakes [...] is both the condition and the product of membership of a field" (Bourdieu 1993 [1981]: 76).

3 This pair of concepts was formulated by Marxist exegetes; Marx himself identified a "class against capital" (or more exactly a "classe vis-à-vis du capital") and a "class for itself" (Andrew 1983) in The Poverty of Philosophy (Marx 1984 [1847]: 79). Marx also made a distinction between class in the sense of an "enormous mass whose members live in similar conditions" and class whose members enter "into manifold relations with each other" (Marx 1898 [1852]: 62). We thank Samuel Coavoux, a fellow contributor to this issue, for originally suggesting this transposition. 
et de la culture si on parvient à mettre en évidence l'existence d'une population de sociologues de l'art et de la culture en soi et pour soi distincte de la population des sociologues dans son ensemble, et ce d'autant mieux que sociologues en soi et sociologues pour soi se trouvent plus entièrement confondu $\cdot e \cdot s$.

L'hypothèse, pour pouvoir être testée, nécessite de l'être sur une population suffisamment large pour ne pas être composée a priori que de sociologues de l'art et de la culture en soi et pour soi et suffisamment étroite pour pouvoir être effectivement étudiée. Ainsi, prendre pour terrain les sociologues ayant publié dans des revues de sociologie de l'art ou de la culture, voire ayant communiqué dans des instances portant « art » ou « culture » dans leur appellation (telles que le réseau thématique $\mathrm{n}^{\circ} 14$ "Sociologie des arts et de la culture » de l'Association française de sociologie [AFS]), aurait permis de délimiter les contours d'une population de sociologues de l'art et de la culture pour soi, c'est-à-dire identifiée.es comme tel.le. $s$ et étant vraisemblablement forcé.e. $s$ de s'identifier du même coup, et au moins pour partie, comme tel $\cdot \mathrm{le} \cdot \mathrm{s}^{4}$, mais n'aurait pas permis de savoir dans quelle mesure cette population réunissait effectivement l'ensemble des sociologues de l'art et de la culture en soi, c'est-à-dire se consacrant essentiellement à la sociologie de terrains « artistiques » ou « culturels ". En confondant a prior population des sociologues en soi et population des sociologues pour soi, un tel choix méthodologique impliquait de présupposer l'autonomie plutôt que de la questionner. Fallait-il au contraire considérer une population exhaustive de sociologues et chercher à savoir si, parmi eux·elles, se trouvait une sous-population nettement distincte caractérisée par sa spécialisation objective et subjective

4 Cette hypothèse gagnerait à être vérifiée, notamment au moyen d'entretiens. Pourtant tout laisse à penser qu'il en va, à cet égard, de même pour l'AFS que pour l'American Sociological Association : " Au-delà même de la from the population of sociologists as a whole, especially in that sociologists in themselves and sociologists for themselves are more fully conflated.

For the purposes of testing this hypothesis, we needed a population that was large enough not to be composed solely of sociologists of art and culture in themselves and for themselves, but small enough to be analysed effectively. Selecting sociologists who had published in journals specializing in the sociology of art or of culture, or who had presented papers at events held by institutions with "art" or "culture" in their name (such as the Association française de sociologie [AFS] thematic network\#14 [RT14] named Sociologie des arts et de la culture), admittedly would have enabled us to trace the outlines of a population of sociologists of art and culture for themselves in the sense that they are identified as such and most likely forced to identify as such at least to some degree as a result ${ }^{4}$. Yet this would not have enabled us to establish to what extent that population actually brought together all sociologists of art and culture in themselves, meaning those sociologists who essentially work in "artistic" or "cultural" settings. By merging the populations of sociologists in themselves and of sociologists for themselves a priori, that methodological choice meant assuming autonomy rather than questioning it. By contrast, we might have

4 This hypothesis would need to be verified, for example by conducting interviews, but everything suggests that what applies to the American Sociological Association also applies to the AFS here: "Beyond the socialization that is nourished by the sections, their respective themes confer on researchers a professional identity that is central to their professional trajectory. Many researchers define themselves first in terms of thei membership in one of them rather than of belonging to a given theoretical school or using a particular method" (Ollion 2011: 289). 
en sociologie de l'art et de la culture ? Mais comment déterminer les contours d'une telle population exhaustive ? La démarche courrait alors le risque d'être soit empiriquement irréaliste, soit aveugle à l'arbitraire de la définition de départ. En s'intéressant par exemple à l'ensemble des individus ayant soutenu une thèse en sociologie sur une période définie, on excluait a priori tout un ensemble d'individus sur la simple base du statut, de l'appartenance disciplinaire et de l'origine nationale.

II fallait donc retenir pour terrain d'enquête un sous-espace de la sociologie qui minimise les « droits d'entrée » (Mauger 2006) tout en maximisant l'hétérogénéité de ses membres. L'espace des congrès de l'AFS remplit cette double condition. Celui-ci ne peut pas être "considéré comme représentatif de la sociologie française " (Saint Léger \& Van Meter 2005) : non seulement des postulant·e.s voient leurs communications refusées à chaque édition (quoique la sélection opérée soit en général peu sévère), mais surtout, tou.te.s n'y postulent pas (bien que les congrès de l'AFS fassent figure d'événement relativement incontournable dans le champ sociologique). Cependant, ces congrès rassemblent une population très large puisqu'ils réunissent tous les deux (ou parfois trois) ans plus d'un millier de communicant.e.s de nationalités diverses, aux ancrages disciplinaires et aux statuts variés, réparti·e-s entre une cinquantaine de réseaux thématiques [par la suite : RT]. En outre, la prise en compte de plusieurs éditions du même événement permet de limiter les biais de sélection institutionnelle. Ainsi, ces

socialisation que réalisent les sections, leurs thèmes respectifs fournissent une identité professionnelle centrale dans la trajectoire professionnelle d'un chercheur. Plutôt que leur appartenance à une école théorique ou leur usage d'une méthode, nombreux sont les chercheurs qui se définissent d'abord par leur inscription dans l'une d'entre elles » (Ollion 2011 : 289). sought to consider an exhaustive population of sociologists to ascertain if there was a clearly distinct sub-population among them, characterized by its objective and subjective specialization in the sociology of art and culture. But how would we have defined the outlines of such an exhaustive population? This approach risked being either empirically unrealistic or blind to the arbitrariness of the initial definition. If, for instance, we decided to consider all the individuals who completed a $\mathrm{PhD}$ in sociology over a given period, this would mean leaving out an entire set of individuals simply on the basis of status, disciplinary affiliation, and national origin.

Our fieldwork site thus had to be a sub-space of sociology that minimized "costs of entry" (Mauger 2006) while maximizing the heterogeneity of its members - a twofold condition met by the space of the AFS congresses. The latter cannot be "considered as representative of French sociology" (Saint Léger \& Van Meter 2005): not only do potential participants see their papers turned down each year (although selection is in general not very tough), but also, and most importantly, not everyone applies to participate in them (although the AFS congresses are important events in the sociological field). Yet these congresses bring together a very broad population: every two (sometimes three) years, they attract over a thousand participants from various countries, with varied disciplinary backgrounds and statuses, distributed between roughly fifty thematic networks [from now on: RT]. Also, taking into account several editions of the same event allowed us to reduce institutional selection biases. Ultimately, these congresses are just as valuable for the study of sociologists of art and culture as the Salons for the study of artists in the first half of the nineteenth century (Sofio 2009: 25). 
congrès présentent le même intérêt pour l'étude des sociologues de l'art et de la culture que les Salons pour l'étude des artistes de la première moitié du XIX ${ }^{e}$ siècle (Sofio 2009 : 25).

Les contours de la population des communicant $\cdot e \cdot s$ sur l'art et la culture.

Notre population est constituée des 349 individus ayant effectué au moins une communication sur l'art et la culture lors des cinq premiers congrès de l'AFS (Villetaneuse en 2004, Bordeaux en 2006, Paris en 2009, Grenoble en 2011 et Nantes en 2013), quelle que soit leur discipline d'inscription et dans quelque RT que ce soit 5 . Ces individus ont été identifiés à partir de la lecture des titres de toutes les communications programmées ${ }^{6}$ et des résumés en cas de doute sur leur propos.

Nous considérons comme « communication sur l'art et la culture » $(\mathrm{N}=465)$ les 147 communications effectuées au RT14 mais aussi les 297 communications, effectuées dans d'autres RT, assimilables à celles du RT14 parce qu'elles fondent leur propos sur les mêmes terrains (indiqués ici par ordre décroissant de fréquence dans le corpus) : la littérature, la musique, les arts plastiques et numériques, les films et les séries télévisées, la danse, le théâtre, l'architecture, le discours savant sur l'art et la culture luimême, les politiques publiques culturelles, le cirque, le patrimoine, l'artisanat d'art, la photographie, les arts de la performance ou la bande-dessinée. Ainsi, nous avons inclus une communication réalisée en dehors du RT14, consacrée aux rapports de domination dans l'œuvre de Werner Herzog, car le terrain (l'œuvre d'un cinéaste) relevait de l'art et de la

5 Les sessions plénières ou semi-plénières n'ont pas été prises en compte car il est bien plus difficile d'y communiquer. Le terme « RT » inclut ici les groupes thématiques (GT) et les groupes de recherche (GR).

$6 \quad$ L'analyse porte ainsi sur les communications sélectionnées et non sur celles ayant effectivement eu lieu, puisqu'il se peut que des défections surviennent après l'édition des programmes.
Outlining the Population of Speakers on Art and Culture

Our population is made up of the 349 individuals who presented a paper on art and culture at least once during the first five AFS congresses (Villetaneuse 2004, Bordeaux 2006, Paris 2009, Grenoble 2011, and Nantes 2013), regardless of their disciplinary affiliation or thematic network 5 . We identified these individuals by going through the titles of all scheduled presentations ${ }^{6}$ and the abstracts in cases where their content was uncertain.

We consider "papers on art and culture" $(\mathrm{N}=465)$ to comprise the 147 presentations given within the thematic network RT14, but also the 297 presentations given in other thematic networks that could be grouped with those of RT14 because they were focused on similar objects of study (listed here in descending order of frequency in the corpus): literature, music, visual and digital art, film and TV series, dance, theatre, architecture, scholarly discourse on art and culture, cultural public policies, the circus, heritage, arts and crafts, photography, performing arts, and comics and graphic novels. For instance, we included a paper presented outside of RT14 on power relations in the work of Werner Herzog because its contents (the work of a film director) was directly related to the definition of art and culture used in RT14.

5 Plenary and semi-plenary sessions were not taken into consideration because presenting papers there is much more difficult. Here the terms "thematic network" and "RT" encompass thematic groups (GT) and research groups (GR).

6 Our analysis concerns selected papers-not the presentations that actually took place, as cancellations sometimes occur after the programme has been published. 
culture au sens du RT14. Des communications similaires ont lieu au RT14 : c'est par exemple le cas d'une intervention consacrée à la violence et aux rapports de domination dans les romans d'Amélie Nothomb. De manière marginale, nous avons également intégré 15 communications traitant de design, de publicité, de sketches humoristiques ou de création de parfum car, quoique ces terrains n'aient pas été investigués par le RT14 jusqu'en 2013, la dimension créative de ces pratiques était mise en avant ; enfin, nous avons inclus 6 communications portant sur d'autres terrains, mais les comparant aux terrains artistiques ou faisant référence à des travaux sociologiques réalisés sur l'art et la culture. Tout indique, et notamment notre expérience passée en tant que membres du bureau, que ces communications auraient eu de très fortes chances d'être acceptées au RT14.

En partant du RT14 et de sa définition (française ${ }^{7}$ ) de l'art et de la culture tout en incluant des communications ayant eu lieu ailleurs, il s'agissait de prendre acte du fait que cette institution contribue à faire exister objectivement cette thématique et à en définir les contours, sans pour autant réifier les frontières institutionnelles. II s'agissait également de prendre en compte des cas rencontrés lors des premiers examens des programmes : ceux de communicant.e.s intervenant sur la même recherche et dans des termes similaires, à la fois au RT14 et dans un autre RT.

Afin d'analyser cette population de communicant.e.s sur l'art et la culture, nous avons constitué une base de données prosopographique à partir des données figurant dans les programmes de l'AFS et (surtout) de données récoltées sur Internet à propos de chaque communicant·e (CV en ligne, pages personnelles, fichier central des thèses, etc.).

7 II ne faut en effet pas oublier que le périmètre de la sociologie de l'art et de la culture « diffère [...] fortement selon les traditions scientifiques : il est tendanciellement plus restreint dans la sociologie française que dans
Similar papers were presented within RT14, including one on violence and power relations in the novels of Amélie Nothomb. Incidentally, we also included fifteen presentations addressing design, publicity, comedy and perfume creation even though these objects were not investigated within RT14 until 2013, because the creative dimension of the subjects was highlighted. Lastly, we included six presentations which discussed other subjects, but featured comparison with artistic ones or referred to sociological research on art and culture. It is very likely, judging in particular by our own past experience as members of the RT14 board, that these papers would have been accepted in this thematic network.

By starting from RT14 and its (French ${ }^{7}$ ) definition of art and culture while also including papers presented outside that network, we recognized that this institution contributes to the objective existence of the theme and to delineating its outlines, without reifying institutional boundaries. We also wanted to account for cases we had encountered upon our first examinations of the programmes, involving speakers who presented papers on the same research and in similar terms both in RT14 and in another RTs.

For the purposes of analysing this population of speakers on art and culture, we built a prosopographical database drawing on data from the AFS programmes and (mostly) online data on each scholar (online $\mathrm{CV}$, personal pages, Fichier central des thèses which registers every doctoral thesis in France, etc.).

7 It is worth recalling that the scope of the sociology of art and culture "differs [...] strongly depending on scientific traditions: it tends to be narrower in French sociology than in the English-speaking world, where the "sociology of culture' label encompasses sports, clothing, and lifestyles, if not science" (Dubois 2007). 
Notre hypothèse s'inscrivant dans le cadre de la théorie des champs, il paraissait naturel de s'intéresser, au moyen de l'analyse des données multidimensionnelles, aux relations objectives unissant et distinguant les individus de notre population, de manière à mettre en évidence la structure interne de l'espace considéré (e.g. Bourdieu 2012 [1984] à propos du champ scientifique français ; Cappell \& Guterbock 1992 ; Daipha 2001 à propos du champ sociologique états-unien). Cependant, une telle approche interroge moins le périmètre d'un champ ou d'un sous-champ qu'elle ne le présuppose, par construction. 'analyse de réseaux, en venant placer la focale sur les relations non plus objectives mais effectives entre individus, permet au contraire d'en interroger les frontières externes. Quoique peu habituelle dans le cadre de la théorie des champs, elle s'avère ainsi non seulement compatible, mais plus encore complémentaire (Denord 2003 ; Sapiro 2006). Un tel usage de la méthode de l'analyse de réseaux n'est pas novateur ; ce qui l'est davantage est d'y recourir au sujet des congrès de l'AFS, jusqu'ici presque exclusivement étudiés au moyen de l'analyse lexicométrique (Boudesseul 2005 ; Saint Léger \& Van Meter 2005 ; Torny \& Trabal 2006 ; Trabal 2005) voire, plus largement, de l'analyse de discours (Deshayes 2015).

L'étude des communicant·e·s sur l'art et la culture, de leur circulation au sein des différents RT et de leurs positions dans les champs académique et culturel révèle que ni les seuls communicant·e.s du RT14 (partie 1), ni l'ensemble des individus de notre population (partie 2) ne constituent un groupe distinct et fortement investi dans une seule et même spécialité sociologique. La troisième partie met cependant en évidence l'existence d'un groupe de sociologues

le monde anglo-saxon, où le label sociology of culture intègre notamment le sport, les attitudes vestimentaires, les modes de vie, voire la science " (Dubois 2007)
As our hypothesis draws on field theory, we might have been expected to investigate the objective relationships bringing the individuals in our population together or apart, by analysing multidimensional data, in order to evidence the internal structure of the space under consideration (e.g., Bourdieu 1988 [1984] on the French scientific field; Cappell \& Guterbock 1992; Daipha 2001 on the US sociological field). However, this approach does not so much question the perimeter of a field or subfield but pre-constructs it. By focusing not on objective relationships between individuals but on effective ones, network analysis enables us to establish the field's outer boundaries. Although its use is somewhat unusual in field theory, it is not only compatible with it but also complementary (Denord 2003; Sapiro 2006). Using network analysis in this way is not innovative per se; the novelty lies in using it to study AFS congresses, which were previously almost exclusively analysed using lexicometric analysis (Boudesseul 2005; Saint Léger \& Van Meter 2005; Torny \& Trabal 2006; Trabal 2005), or, more broadly, discourse analysis (Deshayes 2015).

The study of speakers on art and culture, of their circulation in the thematic networks and their positions in the academic and cultural fields reveals that neither those presenting a paper in RT14 (part 1) nor the entire population (part 2) forms a distinct group that is strongly invested in the same sociological speciality. However, part 3 evidences the existence of a group of sociologists of art and culture both in themselves and for themselves, who appear to share partly distinctive features, although they do not constitute a genuinely autonomous space. 
de l'art et de la culture à la fois en soi et pour soi, qui semblent présenter des propriétés en partie spécifiques sans pour autant constituer un espace véritablement autonome.

\section{Le RT14 comme sous-champ ?}

Selon le premier président de l'AFS, Daniel Bertaux, les RT sont "des lieux de mise en commun et d'approfondissement des savoirs spécialisés ${ }^{8}$ "; et le RT14 de se revendiquer " espace de réflexion sur le sous-champ disciplinaire qu'il contribue à fédérer ${ }^{9} "$. II faut donc commencer par se demander dans quelle mesure le RT14 constitue effectivement un sous-espace autonome au sein de l'espace des congrès de l'AFS. L'analyse des lieux où on y parle d'art et de culture montre alors que le RT14 n'est ni monopolistique,

ni isolé.

\subsection{Des sociologues dispersé·e·s}

On ne communique pas nécessairement au sein du réseau consacré à l'art et la culture lorsqu'on communique à propos d'art et de culture : tel est l'apparent paradoxe qui ressort de l'analyse des communications en fonction des lieux qui les ont accueillies. II n'y a qu'à classer, selon leur RT d'inscription, les 465 communications recensées pour se rendre compte que le RT14 n'est qu'un RT parmi (beaucoup) d'autres de production et de diffusion des recherches traitant d'art et de culture - quoiqu'il reste sans conteste le plus

important (Tableau 1)

Programme du premier congrès de l'AFS, AFS Éditions, Paris, 2004, p. x

9 Appel à communication du colloque « La "sociologie des arts et de la culture" et ses frontières ", 2014.

\section{Thematic Network RT14 as a Subfield?}

According to the first AFS president, Daniel Bertaux, thematic networks are "venues for sharing and elaborating on specialized knowledge." RT14, for its part, presents itself as a "space for reflection on the disciplinary subfield to which it contributes to uniting9." Accordingly, we must begin by investigating to what extent RT14 effectively constitutes an autonomous subfield within the space of AFS congresses. The analysis of the venues where art and culture are discussed shows that RT14 is neither monopolistic nor isolated.

\subsection{Scattered Sociologists}

Speakers on art and culture do not necessarily speak within the thematic network dedicated to art and culture: such is the apparent paradox that emerges from our analysis of the presentations according to where they were given. The classification by thematic network of the 465 presentations in our corpus shows that RT14 is only one among (many) other thematic network venues for the production and diffusion of research on art and culture-although it undoubtedly remains the most prominent (Table 1).

Programme du premier congrès de l'AFS, AFS Éditions, Paris, 2004, p. x.

Call for papers for the conference "La 'sociologie des arts et de la culture' et ses frontières", 2014. 
Tableau 1. Répartition des communications sur l'art et la culture en fonction des RT

\begin{tabular}{|l|c|c|c|c|c|}
\hline \multicolumn{1}{|c|}{ RT d'inscription } & $\begin{array}{c}\mathrm{Nb} \\
\mathrm{RT}\end{array}$ & $\begin{array}{c}\text { Eff. / } \\
\mathrm{RT}\end{array}$ & $\begin{array}{c}\text { Effectifs } \\
\text { cumulés }\end{array}$ & \% /RT & \% cumulés \\
\hline $\begin{array}{l}\text { RT14 Sociologie des arts et } \\
\text { de la culture }\end{array}$ & 1 & $\mathbf{1 4 7}$ & 147 & $\mathbf{3 1 , 6}$ & 31,6 \\
\hline $\begin{array}{l}\text { RT1 Savoirs, travail et } \\
\text { professions }\end{array}$ & 1 & $\mathbf{5 3}$ & 200 & $\mathbf{1 1 , 4}$ & 43,0 \\
\hline $\begin{array}{l}\text { RT27 Sociologie des } \\
\text { intellectuels }\end{array}$ & 1 & $\mathbf{5 2}$ & 252 & $\mathbf{1 1 , 2}$ & 54,2 \\
\hline $\begin{array}{l}\text { RT15 Jeunesse, Âges de vie, } \\
\text { Génération }\end{array}$ & 1 & $\mathbf{1 7}$ & 269 & $\mathbf{3 , 7}$ & 57,8 \\
\hline $\begin{array}{l}\text { GT47 Sociologie visuelle et } \\
\text { filmique }\end{array}$ & 1 & $\mathbf{1 5}$ & 284 & $\mathbf{3 , 2}$ & 61,1 \\
\hline $\begin{array}{l}\text { RT10 Sociologie de la } \\
\text { connaissance RT37 (médias) }\end{array}$ & 2 & $\mathbf{1 3}$ & 310 & $\mathbf{2 , 8}$ & 66,7 \\
\hline RT4 (éducation, formation) & 1 & $\mathbf{1 2}$ & 322 & $\mathbf{2 , 6}$ & 69,2 \\
\hline RT23 (travail, activités) & 1 & $\mathbf{1 1}$ & 333 & $\mathbf{2 , 4}$ & 71,6 \\
\hline $\begin{array}{l}\text { RT5 Classes, inégalités, } \\
\text { fragmentations }\end{array}$ & 1 & $\mathbf{1 0}$ & 343 & $\mathbf{2 , 2}$ & 73,8 \\
\hline RT28 (sexualité) RT31 (sport) & 2 & $\mathbf{9}$ & 361 & $\mathbf{1 , 9}$ & $\mathbf{7 7 , 6}$ \\
\hline $\begin{array}{l}\text { RT22 (parcours de vie) RT41 } \\
\text { Corps, technique et société }\end{array}$ & 2 & $\mathbf{8}$ & 377 & $\mathbf{1 , 7}$ & 81,1 \\
\hline $\begin{array}{l}\text { RT3 (déviance) RT11 } \\
\text { (consommation) } \\
\text { RT24 (rapports sociaux } \\
\text { RT35 (monde associatif) }\end{array}$ & 4 & $\mathbf{7}$ & 405 & $\mathbf{1 , 5}$ & 87,1 \\
\hline RT9 (ville) & $\mathbf{6}$ & $\mathbf{6}$ & 411 & $\mathbf{1 , 3}$ & 88,4 \\
\hline $\begin{array}{l}\text { RT12 Sociologie économique } \\
\text { RT21 Mouvements sociaux } \\
\text { RT25 (emploi) RT29 (sciences } \\
\text { et techniques) RT39 (identité) } \\
\text { GT45 (conflits) }\end{array}$ & 6 & $\mathbf{5}$ & 441 & $\mathbf{1 , 1}$ & 94,8 \\
\hline
\end{tabular}

Table 1. Distribution of papers on art and culture in the thematic networks

\begin{tabular}{|l|c|c|c|c|c|}
\hline \multicolumn{1}{|c|}{ Thematic network (RT) registration } & $\begin{array}{c}\text { No. } \\
\text { RT }\end{array}$ & $\begin{array}{c}\text { Papers } \\
\text { /RT }\end{array}$ & $\begin{array}{c}\text { Total } \\
\text { papers }\end{array}$ & $\begin{array}{c}\% \\
\text { /RT }\end{array}$ & Total \% \\
\hline RT14 Sociology of arts and culture & 1 & $\mathbf{1 4 7}$ & 147 & $\mathbf{3 1 . 6}$ & 31.6 \\
\hline $\begin{array}{l}\text { RT1 Knowledge, labour and } \\
\text { occupations }\end{array}$ & 1 & $\mathbf{5 3}$ & 200 & $\mathbf{1 1 . 4}$ & 43.0 \\
\hline RT27 Sociology of intellectuals & 1 & $\mathbf{5 2}$ & 252 & $\mathbf{1 1 . 2}$ & 54.2 \\
\hline $\begin{array}{l}\text { RT15 Youth, stages of life and } \\
\text { generation }\end{array}$ & 1 & $\mathbf{1 7}$ & 269 & $\mathbf{3 . 7}$ & 57.8 \\
\hline GT47 Visual and filmic sociology & 1 & $\mathbf{1 5}$ & 284 & $\mathbf{3 . 2}$ & 61.1 \\
\hline $\begin{array}{l}\text { RT10 Sociology of knowledge RT37 } \\
\text { (media) }\end{array}$ & 2 & $\mathbf{1 3}$ & 310 & $\mathbf{2 . 8}$ & 66.7 \\
\hline RT4 (education, training) & 1 & $\mathbf{1 2}$ & 322 & $\mathbf{2 . 6}$ & 69.2 \\
\hline RT23 (work, activities) & 1 & $\mathbf{1 1}$ & 333 & $\mathbf{2 . 4}$ & 71.6 \\
\hline $\begin{array}{l}\text { RT5 Class, inequalities, } \\
\text { fragmentations }\end{array}$ & 1 & $\mathbf{1 0}$ & 343 & $\mathbf{2 . 2}$ & 73.8 \\
\hline RT28 (sexuality) RT31 (sports) & 2 & $\mathbf{9}$ & 361 & $\mathbf{1 . 9}$ & 77.6 \\
\hline $\begin{array}{l}\text { RT22 (life courses) RT41 Body, } \\
\text { technology and society }\end{array}$ & 2 & $\mathbf{8}$ & 377 & $\mathbf{1 . 7}$ & 81.1 \\
\hline $\begin{array}{l}\text { RT3 (deviance) RT11 (consumption) } \\
\text { RT24 (social relations } \\
\text { profit sector) }\end{array}$ & 4 & $\mathbf{7}$ & 405 & $\mathbf{1 . 5}$ & 87.1 \\
\hline RT9 (the city) & $\mathbf{1 0}$ & $\mathbf{6}$ & 411 & $\mathbf{1 . 3}$ & 88.4 \\
\hline $\begin{array}{l}\text { RT12 Economic sociology } \\
\text { RT21 Social movements } \\
\text { RT25 (employment) RT29 (science } \\
\text { and technology) RT39 (identity) } \\
\text { GT45 (conflicts) }\end{array}$ & $\mathbf{6}$ & $\mathbf{5}$ & 441 & $\mathbf{1 . 1}$ & 94.8 \\
\hline $\begin{array}{l}\text { RT2 (migrations) RT13 (law) RT26 } \\
\text { (networks) RT30 (management) } \\
\text { RT34 (policy) RT42 (elites**) }\end{array}$ & $\mathbf{6}$ & & & $\mathbf{0 . 9}$ & 100.0 \\
\hline
\end{tabular}




\begin{tabular}{|c|c|c|c|c|c|}
\hline RT d'inscription & $\begin{array}{l}\mathrm{Nb} \\
\mathrm{RT}\end{array}$ & $\begin{array}{c}\text { Eff. / } \\
\text { RT }\end{array}$ & $\begin{array}{l}\text { Effectifs } \\
\text { cumulés }\end{array}$ & $\% / R T$ & $\%$ cumulés \\
\hline $\begin{array}{l}\text { RT2 (migrations) RT13 } \\
\text { (droit) RT26 (réseaux) RT30 } \\
\text { (gestion) RT34 (politique) } \\
\text { RT42 (élites }{ }^{\star \star} \text { ) }\end{array}$ & 6 & 4 & 465 & 0,9 & 100,0 \\
\hline $\begin{array}{l}\text { RT6 (protection sociale) } \\
\text { RT16 Sociologie clinique } \\
\text { RT17 Gestion politique du } \\
\text { corps et des populations }\end{array}$ & 3 & 3 & 474 & 0,6 & 101,9 \\
\hline $\begin{array}{l}\text { RT7 (vieillesse) RT18 (2004: } \\
\text { approches plurielles du Sujet, } \\
\text { 2013 : relations pro.) RT33 } \\
\text { (famille) RT36 (théories) } \\
\text { RT38 (environnement) RT40 } \\
\text { (institutions) GT44 (justice } \\
\text { sociale) }\end{array}$ & 7 & 2 & 488 & 0,4 & 104,9 \\
\hline RT20 Méthodes & 1 & 1 & 489 & 0,2 & 105,2 \\
\hline TOTAL & 42 & & $489^{\star \star \star *}$ & & $105,2 * \star *$ \\
\hline
\end{tabular}

*Le nom du RT24 a été sensiblement modifié entre 2004 et 2013, passant de « Travail (productif et reproductif), rapports sociaux, rapports de genre » à « Genre, Classe, Race. Rapports sociaux et construction de l'altérité ".

**Le RT42 était consacré à l'origine à la " sociologie de l'expertise des sciences humaines et sociales ", mais cette spécialité a été intégrée en 2006 au RT27. Nous retenons ici le terme d'« élites » pour caractériser le RT42 puisque la « sociologie des élites » est son intitulé depuis 2011, et qu'aucune des communications de notre corpus rattachées au RT42 n'est antérieure à 2011.

***Le total est supérieur à 465 et à $100 \%$ en raison de la comptabilisation double (22) voire triple (1) des 23 communications effectuées dans le cadre de sessions conjointes entre plusieurs RT.

Lecture : on dénombre 13 communications sur l'art et la culture parmi l'ensemble des communications effectuées au RT10, soit 2,8 \% des 465 communications. De même pour le RT37.

\begin{tabular}{|c|c|c|c|c|c|}
\hline Thematic network (RT) registration & $\begin{array}{l}\text { No. } \\
\text { RT }\end{array}$ & $\begin{array}{c}\text { Papers } \\
\text { /RT }\end{array}$ & $\begin{array}{c}\text { Total } \\
\text { papers }\end{array}$ & $\begin{array}{c}\% \\
\text { /RT }\end{array}$ & Total \% \\
\hline $\begin{array}{l}\text { RT6 (social protection) RT16 Clinical } \\
\text { sociology } \\
\text { RT17 Political management of the } \\
\text { body and of populations }\end{array}$ & 3 & 3 & 474 & 0.6 & 101.9 \\
\hline $\begin{array}{l}\text { RT7 (aging) RT18 (2004: plural } \\
\text { approaches to the Subject, 2013: } \\
\text { prof. relations) RT33 (family) RT36 } \\
\text { (theories) RT38 (environment) RT40 } \\
\text { (institutions) GT44 (social justice) }\end{array}$ & 7 & 2 & 488 & 0.4 & 104.9 \\
\hline RT20 Methods & 1 & 1 & 489 & 0.2 & 105.2 \\
\hline TOTAL & 42 & & $489^{\star \star \star}$ & & $105.2^{\star \star \star}$ \\
\hline
\end{tabular}

"The name of RT24 changed between 2004 and 2013, from "(Productive and reproductive) work, social relations, gender relations" to "Gender, class, race. Social relations and the construction of the Other".

${ }^{* *} \mathrm{RT} 42$ originally dealt with the "Sociology of expertise in the human and social science," but this was made a part of RT27 in 2006. We use the term "elites" to refer to RT42 because it has been called "Sociology of elites" since 2011, and there are no pre-2011 papers presented in RT42 in our corpus.

${ }^{* * *}$ The total exceeds 465 papers and $100 \%$ due to the fact that 23 papers were presented in joint sessions between several thematic networks (two for 22 papers, three for one paper).

How to read this table: we found 13 papers on art and culture among the entirety of the presentations made in RT10, amounting to $2.8 \%$ of the 465 papers-numbers are identical in RT37. 
Moins d'un tiers des communications sur l'art et la culture sont effectuées au sein du RT qui s'en réclame. Le premier constat est ainsi celui de la grande dispersion de ces interventions : il n'y a que 7 RT (sur 49), qui plus est d'importance restreinte à l'exception du RT19 (santé), à n'avoir accueilli aucune communication sur l'art et la culture entre 2004 et $2013^{10}$; de plus, les 42 RT à avoir accueilli ces recherches les ont accueillies, dans la quasi intégralité des cas, à plusieurs reprises - signe supplémentaire du fait qu'il est ordinaire, à l'AFS, de communiquer sur l'art et la culture en dehors

du lieu a priori réservé à cette thématique.

Le Tableau 1 révèle par ailleurs que, outre le RT14, 2 RT font figure de réceptacles réguliers de telles communications : le RT1 et le RT27, qui accueillent chacun plus d'une communication sur dix. Ce n'est que réunis ensemble que ces $3 \mathrm{RT}$ parviennent à concentrer plus de $50 \%$ des communications sur l'art et la culture. Mais ces données, parce qu'elles ne prennent pas en compte la taille relative des RT, ne donnent qu'une idée approximative des lieux les plus caractérisés par ces recherches. En rapportant, pour chaque RT, le nombre de communications sur l'art et la culture à l'ensemble des communications effectuées en son sein, le Tableau 2 permet de réévaluer à la hausse l'importance des GT47, RT37 et RT41, et à la baisse l'importance des RT1 et RT4. Ainsi, plus de quatre communications sur dix effectuées au GT47 s'avèrent pouvoir être

10 RT8 Sociologie du militaire $(\approx 90$ communications accueillies entre 2004 et 2013, contre 400 au RT1 et 120 en moyenne par RT), RT19 Santé, médecine, maladie et handicap ( $\approx 200$ communications), GT32 Sociologie et systèmes complexes $(\approx 20)$, RT43 Sociologie et religions $(\approx 80)$, GT46 Formation, certification, qualification $(\approx 30)$, GT48 Articulation vie professionnelle/vie familiale et Recomposition des Temps sociaux $(\approx 20)$ et GT Histoire de la sociologie, devenu GT49 en $2015(\approx 30)$. L'absence de ces RT dans notre corpus est d'autant moins significative que le poids de ces RT est faible.
Less than a third of papers on art and culture were presented in the thematic network dedicated to art and culture. What stands out here is the extent to which these papers are spread between the RTs: only 7 out of 49 networks did not host a single paper on art and culture between 2004 and $2013^{10}$; what is more, they were mostly less prominent networks apart from the health network (RT19). Additionally, almost all of the forty-two networks where research on art and culture was presented included several such papers, which further shows that presenting papers on art and culture outside of the dedicated thematic network is a routine occurrence at AFS congresses.

Table 1 also reveals that apart from RT14, two thematic networks regularly host presentations on art and culture: RT1 and RT27, with more than one in ten papers each. Only taken together do these three networks account for more than 50 per cent of papers on art and culture. However, these data do not take into account the relative size of the networks, and as such only give us a rough idea of the places where this research is most present. By relating the number of papers on art and culture to the overall number of papers presented in each network, Table 2 offers a reassessment of the relative importance of GT47, RT37 and RT41, and downplays that of RT1 and RT4. Thus, more than four out of ten papers presented in GT47 relate to art and culture (making it the second most prominent network on this theme in relative terms), versus barely

10 RT8 "Sociology of the military" (around 90 papers between 2004 and 2013, vs 400 in RT1 and 120 on average by RT), RT19 "Health, medicine, disease and disability" (around 200 papers), GT32 "Sociology and complex systems" ( $\approx 20)$, RT43 "Sociology and religions" $(\approx 80)$, GT46 "Training, certification, qualification" $(\approx 30)$, GT48 "Professional and family life mix" and "Transformation of social times" $(\approx 20)$ and "GT History of sociology," which became GT49 in $2015(\approx 30)$. The absence of these RTs in our corpus has little statistical significance when their weighting is small. 
rattachées à l'art et la culture (ce qui en fait le deuxième réseau sur cette thématique en importance relative), quand elles ne sont guère plus d'une sur dix à pouvoir l'être au sein du RT1 (ce qui en fait le cinquième réseau en importance relative). En somme, 9 RT sur 49 apparaissent particulièrement favorables à l'accueil de communications sur l'art et la culture - soit près d'un cinquième d'entre eux.

Tableau 2. Les RT les plus accueillants pour les communications sur l'art et la culture

\begin{tabular}{|l|c|c|c|}
\hline \multicolumn{1}{|c|}{ RT d'inscription } & $\begin{array}{c}\text { Comm. art et } \\
\text { culture }\end{array}$ & $\begin{array}{c}\text { Nombre total } \\
\text { comm. }\end{array}$ & $\begin{array}{c}\text { \% comm. art et } \\
\text { culture }\end{array}$ \\
\hline $\begin{array}{l}\text { RT14 Sociologie des arts et de la } \\
\text { culture }\end{array}$ & 147 & 147 & 100,0 \\
\hline GT47 Sociologie visuelle et filmique & 15 & 36 & 41,7 \\
\hline RT27 Sociologie des intellectuels & 52 & 172 & 30,2 \\
\hline RT37 Sociologie des médias & 13 & 82 & 15,9 \\
\hline RT1 Savoirs, travail et professions & 53 & 400 & 13,3 \\
\hline $\begin{array}{l}\text { RT15 Jeunesse, Âges de vie, } \\
\text { Génération }\end{array}$ & 17 & 137 & 12,4 \\
\hline $\begin{array}{l}\text { RT10 Sociologie de la } \\
\text { connaissance }\end{array}$ & 13 & 107 & 12,1 \\
\hline RT41 Corps, technique et société & 8 & 72 & 11,1 \\
\hline RT23 Travail, activités, techniques & 11 & 118 & 9,3 \\
\hline TOTAL tous RT confondus & $\mathbf{4 8 9}$ & $\mathbf{5 9 2 1}$ & $\mathbf{8 , 3}$ \\
\hline
\end{tabular}

N.B. : Ne figurent dans ce tableau que les RT au sein desquels les communications sur l'art et la culture sont plus fréquentes que la moyenne $(8,3 \%)$.

Lecture : on dénombre 15 communications sur l'art et la culture parmi les 36 effectuées au GT47, soit $41,7 \%$ des communications du GT47.

Si ces résultats renseignent sur la dispersion des communications, ils ne renseignent pas sur la dispersion des communicant·e.s. À one in ten in RT1 (making it the fifth network in relative terms). Overall, 9 out of 49 networks appear to be particularly likely to host papers on art and culture-nearly one in five networks.

Table 2. RTs with the highest proportion of papers on art and culture

\begin{tabular}{|l|c|c|c|}
\hline Thematic network (RT) registration & $\begin{array}{c}\text { Papers on art } \\
\text { and clt }\end{array}$ & $\begin{array}{c}\text { Overall no. of } \\
\text { papers }\end{array}$ & $\begin{array}{c}\% \text { papers } \\
\text { on art and } \\
\text { clt }\end{array}$ \\
\hline RT14 Sociology of arts and culture & 147 & 147 & 100.0 \\
\hline GT47 Visual and filmic sociology & 15 & 36 & 41.7 \\
\hline RT27 Sociology of intellectuals & 52 & 172 & 30.2 \\
\hline RT37 Sociology of media & 13 & 82 & 15.9 \\
\hline $\begin{array}{l}\text { RT1 Knowledge, labour and } \\
\text { professions }\end{array}$ & 53 & 400 & 13.3 \\
\hline $\begin{array}{l}\text { RT15 Youth, stages of life, } \\
\text { generation }\end{array}$ & 17 & 137 & 12.4 \\
\hline RT10 Sociology of knowledge & 13 & 107 & 12.1 \\
\hline RT41 Body, technology and society & 8 & 72 & 11.1 \\
\hline RT23 Work, activities, technologies & 11 & 118 & 9.3 \\
\hline TOTAL for all thematic networks & $\mathbf{4 8 9}$ & $\mathbf{5 9 2 1}$ & $\mathbf{8 . 3}$ \\
\hline
\end{tabular}

N.B.: This table only features RTs in which papers on art and culture are more frequent than the average $(8.3 \%)$.

How to read this table: we found 15 papers on art and culture among the 36 papers presented at GT47, i.e., $41.7 \%$ of presentations at GT47.

While these findings tell us about how papers are distributed, they do not tell us about how those who present them are distributed. If 
considérer les individus de notre population, le constat s'avère néanmoins similaire : avoir communiqué au RT14 n'est pas la situation la plus courante lorsqu'on parle d'art et de culture, puisque près des deux tiers des communicant·e's concerné·e·s ne l'ont jamais fait. Force est de constater que ce réseau thématique ne détient nullement le monopole de la recherche sur l'art et la culture aux congrès. En outre, avoir communiqué au RT14 est une situation encore moins courante lorsqu'on communique pour la première fois (Tableau 3). Puisque l'inscription d'une communication dans le programme d'un RT ne relève pas du hasard mais d'un acte positif de candidature, il faut en conclure que le RT14 n'est le premier RT auquel on pense pour présenter une communication sur l'art et la culture qu'en termes relatifs.

Tableau 3. Répartition des communicant $\cdot e \cdot s$ sur l'art et la culture en fonction des RT

\begin{tabular}{|l|c|c|}
\hline \multicolumn{1}{|c|}{ Communicant·e·s } & Effectifs & $\%$ \\
\hline Sur l'ensemble des congrès & $\mathbf{3 4 9}$ & $\mathbf{1 0 0 , 0}$ \\
\hline Ayant communiqué uniquement au RT14 & 85 & $\mathbf{2 4 , 4}$ \\
\hline N'ayant pas communiqué au RT14 & 222 & $\mathbf{6 3 , 6}$ \\
\hline Ayant communiqué à la fois au RT14 et hors RT14 & 42 & $\mathbf{1 2 , 0}$ \\
\hline À l'occasion de leur premier congrès & $\mathbf{3 4 9}$ & $\mathbf{1 0 0 , 0}$ \\
\hline Ayant communiqué uniquement au RT14 & 100 & $\mathbf{2 8 , 7}$ \\
\hline N'ayant pas communiqué au RT14 & 234 & $\mathbf{6 7 , 0}$ \\
\hline Ayant communiqué à la fois sur RT14 et hors RT14 & 15 & $\mathbf{4 , 3}$ \\
\hline
\end{tabular}

Ces premiers résultats suggèrent déjà que ce n'est pas parce qu'on communique sur l'art et la culture qu'on se reconnaît inévitablement dans cette spécialité et qu'on est nécessairement un sociologue de l'art et de la culture pour soi. Ils ne disent toutefois rien, à l'inverse, de l'autonomie de la pratique sociologique de ceux.celles qui communiquent au RT14. we consider the individuals in our population, we are led to a similar observation: presenting a paper in RT14 is not the most frequent option for speakers on art and culture-indeed, nearly two thirds of the academics in question have never done so. RT14 therefore certainly does not have a monopoly on research on art and culture at the congresses. The same goes for first-time presentations, for which RT14 is not the most frequent option either (actually even less so) (Table 3). Since the inclusion of a paper in the programme of a given network is not a result of chance but of a deliberate application, we must infer that RT14 is only the first network chosen to present a paper on art and culture in relative terms.

Table 3. Distribution of speakers on art and culture by thematic network

\begin{tabular}{|l|c|c|}
\hline Speakers & Number & $\%$ \\
\hline All congresses considered & $\mathbf{3 4 9}$ & $\mathbf{1 0 0 . 0}$ \\
\hline Presented a paper only in RT14 & 85 & 24.4 \\
\hline Did not present a paper in RT14 & 222 & 63.6 \\
\hline $\begin{array}{l}\text { Presented a paper both in RT14 and } \\
\text { elsewhere }\end{array}$ & 42 & 12.0 \\
\hline At their first congress & $\mathbf{3 4 9}$ & $\mathbf{1 0 0 . 0}$ \\
\hline Presented a paper only in RT14 & 100 & 28.7 \\
\hline Did not present a paper in RT14 & 234 & 67.0 \\
\hline $\begin{array}{l}\text { Presented a paper both in RT14 and } \\
\text { elsewhere }\end{array}$ & 15 & 4.3 \\
\hline
\end{tabular}

These first findings already suggest that speakers presenting papers on art and culture do not necessarily identify with this speciality, and therefore are not necessarily sociologists of art and culture for themselves. Yet the findings tell us nothing about the autonomy of the sociological practice of speakers in RT14. 


\subsection{Des sociologues en dialogue}

Quoique le RT14 soit loin d'être le théâtre unique des recherches sur l'art et la culture, il pourrait faire figure d'espace autonome, investi exclusivement par certain'e.s sociologues. Cependant, le RT14 semble plutôt faire office de réseau incontournable pour nos

communicant $\cdot e \cdot s$

C'est d'abord ce que montre l'analyse des lieux des communications en fonction du nombre d'interventions sur l'art et la culture de chaque communicant·e sur les cinq congrès considérés (Tableau 4) : plus on communique à ce sujet, et plus, d'une part, la probabilité de communiquer exclusivement au RT14 diminue (jusqu'à atteindre $0 \%$ pour 5 communications) et, d'autre part, la probabilité de communiquer notamment au RT14 augmente (jusqu'à atteindre $100 \%$ pour 6 communications). Ce dernier est donc un lieu de passage au moins autant qu'un lieu d'ancrage : lorsqu'on parle régulièrement d'art et de culture aux congrès, il est rare de ne pas intervenir au RT14, et plus rare encore de n'intervenir qu'au RT14 (seuls 10 individus sur 97 ayant communiqué deux fois ou plus sur

l'art et la culture n'ont connu que le RT14).

\subsection{Ecumenical Sociologists}

While RT14 is far from being the only venue for research on art and culture, it could have been an autonomous space where only some sociologists are invested. In practice, however, RT14 rather seems to be a key network for our population of speakers.

This is first shown by the analysis of thematic networks of presentations according to the number of papers on art and culture of each speaker (Table 4): the more a speaker presents papers on the subject, the lower the likelihood of presenting them exclusively in RT14 (down to 0 per cent for five papers) and the higher the likelihood of presenting one in RT14 (up to 100 per cent for six papers). When one regularly presents papers on art and culture at the congresses, not doing so in RT14 is a rare occurrence; doing so only in RT14 is an even rarer occurrence (only 10 out of 97 speakers who presented two or more papers on art and culture did so only in RT14) 
Tableau 4. Importance du RT14 pour les communicant·e·s selon le nombre de leurs communications sur l'art et la culture

\begin{tabular}{|c|c|c|c|c|c|c|c|c|}
\hline \multirow{2}{*}{$\begin{array}{c}\text { Nombre } \\
\text { de comm. }\end{array}$} & \multicolumn{2}{|c|}{$\begin{array}{c}\text { Uniquement au } \\
\text { RT14 }\end{array}$} & \multicolumn{2}{|c|}{$\begin{array}{c}\text { Jamais au } \\
\text { RT14 }\end{array}$} & \multicolumn{2}{|c|}{$\begin{array}{c}\text { À la fois au RT14 } \\
\text { et hors RT14 }\end{array}$} & \multicolumn{2}{|c|}{ TOTAL } \\
\cline { 2 - 9 } & Effectifs & $\%$ & Effectifs & $\%$ & Effectifs & $\%$ & Effectifs & $\%$ \\
\hline 1 & 75 & 29,8 & 176 & 69,8 & $1^{*}$ & 0,4 & 252 & 100,0 \\
\hline 2 & 7 & 13,0 & 34 & 63,0 & 13 & 24,1 & 54 & 100,0 \\
\hline 3 & 2 & 8,3 & 9 & 37,5 & 13 & 54,2 & 24 & 100,0 \\
\hline 4 & 1 & 9,1 & 2 & 18,2 & 8 & 72,7 & 11 & 100,0 \\
\hline 5 & 0 & 0,0 & 1 & 16,7 & 5 & 83,3 & 6 & 100,0 \\
\hline 6 & 0 & 0,0 & 0 & 0,0 & 2 & 100,0 & 2 & 100,0 \\
\hline TOTAL & $\mathbf{8 5}$ & & $\mathbf{2 2 2}$ & & $\mathbf{4 2}$ & & $\mathbf{3 4 9}$ & \\
\hline
\end{tabular}

"Communication dans le cadre d'une session conjointe au RT14 et au RT37.

Lecture : parmi les 54 communicant·e.s ayant effectué 2 communications sur l'art et la culture, 7 les ont effectuées uniquement au RT14, soit $13 \%$ d'entre eux.

Mais le caractère quasi incontournable du RT14 pour les communicant.e.s sur l'art et la culture est mieux encore mis en évidence par l'analyse de réseaux, qui permet d'étudier les liens entre RT. On ne considère plus désormais que les 97 individus ayant communiqué au moins deux fois à propos d'art et de culture, ainsi que les 11 individus ayant communiqué une seule fois à ce propos mais dans le cadre de sessions conjointes ${ }^{11}$, faisant ainsi le lien, quoique d'une autre manière, entre deux RT. Ces 108 individus, qui représentent $30,9 \%$ de la population mais $54,8 \%$ des 465 communications, ont fait le lien à 344 reprises entre $39 \mathrm{RT}$ différents ${ }^{12}$ au travers de leurs différentes communications.

11 Au total, les sessions conjointes concernent 25 individus sur les 108 mais seulement 23 communications sur 255 , soit $9 \%$, et 25 liens sur 344 , soit $7,3 \%$. Leur influence est donc limitée sur la structuration du réseau.

12 Les graphes ne font apparaître que 39 nœuds, et non 42 comme le nombre de RT ayant accueilli des communications sur l'art et la culture, car ne sont intervenus dans les RT18, RT33 et RT38 que des individus ayant communiqué une seule fois, et lors de sessions non conjointes.
Table 4. Importance of RT14 for speakers according to number of papers presented on art and culture

\begin{tabular}{|c|c|c|c|c|c|c|c|c|}
\hline \multirow{2}{*}{$\begin{array}{c}\text { No. of } \\
\text { papers }\end{array}$} & \multicolumn{2}{|c|}{ Only in RT14 } & \multicolumn{3}{|c|}{ Never in RT14 } & \multicolumn{2}{c|}{$\begin{array}{c}\text { Both in RT14 and } \\
\text { elsewhere }\end{array}$} & \multicolumn{2}{|c|}{ TOTAL } \\
\cline { 2 - 10 } & Number & $\%$ & Number & $\%$ & Number & $\%$ & Number & $\%$ \\
\hline 1 & 75 & 29.8 & 176 & 69.8 & $1^{*}$ & 0.4 & 252 & 100.0 \\
\hline 2 & 7 & 13.0 & 34 & 63.0 & 13 & 24.1 & 54 & 100.0 \\
\hline 3 & 2 & 8.3 & 9 & 37.5 & 13 & 54.2 & 24 & 100.0 \\
\hline 4 & 1 & 9.1 & 2 & 18.2 & 8 & 72.7 & 11 & 100.0 \\
\hline 5 & 0 & 0.0 & 1 & 16.7 & 5 & 83.3 & 6 & 100.0 \\
\hline 6 & 0 & 0.0 & 0 & 0.0 & 2 & 100.0 & 2 & 100.0 \\
\hline TOTAL & $\mathbf{8 5}$ & & $\mathbf{2 2 2}$ & & $\mathbf{4 2}$ & & $\mathbf{3 4 9}$ & \\
\hline
\end{tabular}

*Paper presented in a joint session RT14/RT37.

How to read this table: among the 54 speakers who presented two papers on art and culture, 7 presented their papers only in RT14, i.e., $13 \%$.

The virtual inevitability of RT14 for speakers on art and culture is made even more visible by network analysis, which probes the relations between the RT. For its purposes, we only considered the ninety-seven individuals who presented at least two papers on art and culture, as well as the eleven individuals who presented only one paper on art and culture in a joint session ${ }^{11}$, thereby linking two thematic networks, albeit in a different way. These 108 individuals, who account for 30.9 per cent of the population and 54.8 per cent of the 465 papers, linked 39 different RTs on 344 occasions $^{12}$.

11 Overall, joint sessions involved 25 out of the 108 individuals, but only 23 out of 255 papers $(9 \%)$, and 25 out of 344 ties $(7.3 \%)$. Their influence on the structure of the network is accordingly small.

12 The graphs only feature 39 nodes - not 42 , the number of networks which have hosted presentations of papers on art and culture-, as in RT18, RT33 and RT38, scholars presented only one paper in a non-joint session. 


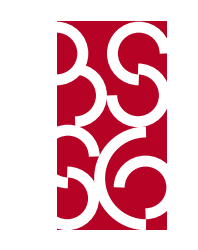

L'analyse de réseaux de réseaux thématiques

L'analyse de réseaux peut être sommairement définie comme l'étude des relations qu'un ensemble d'unités sociales entretiennent entre elles (Mercklé 2004 : 4). En l'espèce, les unités considérées ne sont pas des individus mais des institutions, à savoir les RT de l'AFS. II y a relation entre deux RT dès lors qu'un individu a communiqué soit à la fois dans l'un et l'autre, soit dans le cadre d'une session conjointe.

Puisqu'il s'agit de relations mutuelles non hiérarchisées, les graphes qui en rendent compte sont non orientés. Chaque rond (qu'on appelle « nœud " ou « sommet » en analyse de réseaux) représente un RT, chaque trait (« lien » ou « arête ») entre deux ronds marque l'existence d'une relation entre deux $\mathrm{RT}$, et l'épaisseur de chaque trait est proportionnelle à la fréquence de cette relation. La longueur des traits n'a quant à elle aucune signification et dépend de l'algorithme mobilisé.

On appelle « degré » le nombre de relations (ou type de liens) qu'un nœud entretient avec d'autres nœuds, c'està-dire, en l'espèce, le nombre de RT auquel tel RT est connecté. On peut connaître le degré de chaque nœud à partir des graphes en comptabilisant le nombre de traits qui partent de lui. On appelle « degré pondéré » le nombre total de liens qu'un nœud entretient avec d'autres nœuds, chaque relation (degré) pouvant donner lieu à plusieurs liens. On peut savoir par approximation si un nœud a un fort ou faible degré pondéré à partir des graphes en prenant en compte le nombre et l'épaisseur de ses arêtes.

Les graphes ont été réalisés avec le logiciel libre Gephi, version 0.9.1. Nous avons eu recours à l'algorithme de spatialisation Force Atlas (force de répulsion : 10 000, force d'attraction : 10). Cet algorithme de type « force-based » est particulièrement adapté à la mise en évidence de distances et de proximités car il implique que les nœuds se repoussent
Network Analysis of Thematic Networks

Network analysis can be summarily defined as the study of the relations between a given set of social units (Mercklé 2004: 4). In the case at hand, the units under consideration are not individuals but institutionsnamely the thematic networks (RT) of the AFS. A relation exists between two RTs whenever an individual has presented a paper either in both, or at a joint session.

As these are non-hierarchized mutual relations, the graphs describing them are undirected. Each circle (called "node" or "vertex" in network analysis) represents a RT; each line ("tie" or "edge") between two circles indicates the existence of a relation between two RTs; and the thickness of each line is proportionate to the frequency of this relation. The length of the lines has no signification and depends on the algorithm used.

The number of relations (or type of ties) between a node and others - here the number of RTs with which a given RT is connected-is called its "degree." The degree of each node can be established by counting the number of lines starting from the node in question. The total number of ties between one node and others is the "weighted degree"-each relation (degree) may give rise to one or several ties. We can have an approximate idea of whether a node has a strong or weak weighted degree based on the graphs by considering the number and thickness of the lines.

The graphs were made using the open-source software Gephi (0.9.1 version). We used the layout algorithm Force

Atlas (repulsion strength: 10,000; attraction strength: 10). This force-based algorithm is particularly suited to evidencing distances and proximities, as it involves nodes repulsing each other like magnets, and edges attracting nodes that 
comme des aimants, tandis que les liens attirent les nœuds qu'ils connectent comme des ressorts ; ces forces mettent les nœuds en mouvement, jusqu'à ce qu'un point d'équilibre soit atteint (Jacomy, Venturini, Heymann, Bastian 2014 : 2).

Le Graphe 1 fait apparaître de manière incontestable le caractère central du RT14 en matière d'art et de culture : alors qu'il aurait pu être un RT important quantitativement tout en étant fortement isolé, ou du moins excentré, non seulement le nœud RT14 présente de loin le degré le plus important (27, contre 13 pour le RT1 ${ }^{13}$, ce qui signifie qu'il est en lien avec plus de la moitié des autres RT), mais la représentation de la taille des nœuds selon leur indice de centralité (betweenness centrality) expose clairement le rôle charnière du RT14 au sein de l'espace ainsi construit ${ }^{14}$.

Il faut en déduire que le RT14, en accueillant dans ses sessions des communicant·e.s intervenant également sur la même thématique dans un grand nombre d'autres RT, participe au dialogue entre les individus traitant d'art et de culture. Plus encore, il dispose de «trous structuraux » (Burt 1992) autour de lui et se pose par conséquent en intermédiaire incontournable entre plusieurs RT : il est ainsi le seul à relier les RT21, RT36 et RT40 au reste du réseau. En son absence, non seulement 3 RT se retrouveraient

13 Ces chiffres n'incluent pas les « boucles », c'est-à-dire les liens d'un RT vers lui-même (plusieurs communications au sein d'un même RT au fil des congrès par un même individu).

14 La centralité betweenness se fonde sur la prise en compte de l'ensemble des plus courts chemins existant entre chaque paire de nœuds, c'est-à-dire des chemins les plus directs, minimisant le nombre de nœuds intermédiaires. Cette centralité est proportionnelle, pour chaque nœud, au rapport entre le nombre de plus courts chemins passant par ce nœud et l'ensemble des plus courts chemins. La centralité betweenness est ainsi très élevée pour les nœuds par lesquels passent la plupart des plus courts chemins. they connect like springs; these forces put nodes in motion until a balance is reached (Jacomy, Venturini, Heymann, Bastian 2014: 2).

Graph 1 clearly displays the centrality of RT14 in research on art and culture. While it could have been a quantitatively significant but highly isolated-or at least peripheral-network, not only is the RT14 node characterized by the highest degree by far (twentyseven versus thirteen for $R T 1^{13}$, meaning it is connected to more than half of the other RTs), but the representation of node size according to its betweenness centrality also evidences its key role within this space ${ }^{14}$

We must infer from this that RT14, by hosting speakers who also present papers on the same themes in many other RTs, contributes to the dialogue between the individuals who conduct research on art and culture. Additionally, there are "structural holes" (Burt 1992) around it, and as a result it acts as a key intermediary between several RTs, being for instance the only one to link RT21, RT36, and RT40 to the rest of the network. Without it, not only would these three RTs be isolated, but the network would be less dense and the paths between nodes longer. Counterintuitively, RT14 appears

13 These numbers do not include "loops," meaning the ties of a node with itself (in the event where the same individual has presented several papers in the same RT at different congresses)

14 Betweenness centrality is a measure of centrality based on shortest paths between each pair of nodes-i.e., the most direct ones, with a minimal number of intermediary nodes. For each node, centrality is proportionate to the ratio between the number of the shortest paths going through that node and the overall number of shortest paths. Betweenness centrality is therefore very high for nodes through which most of the shortest paths pass. 


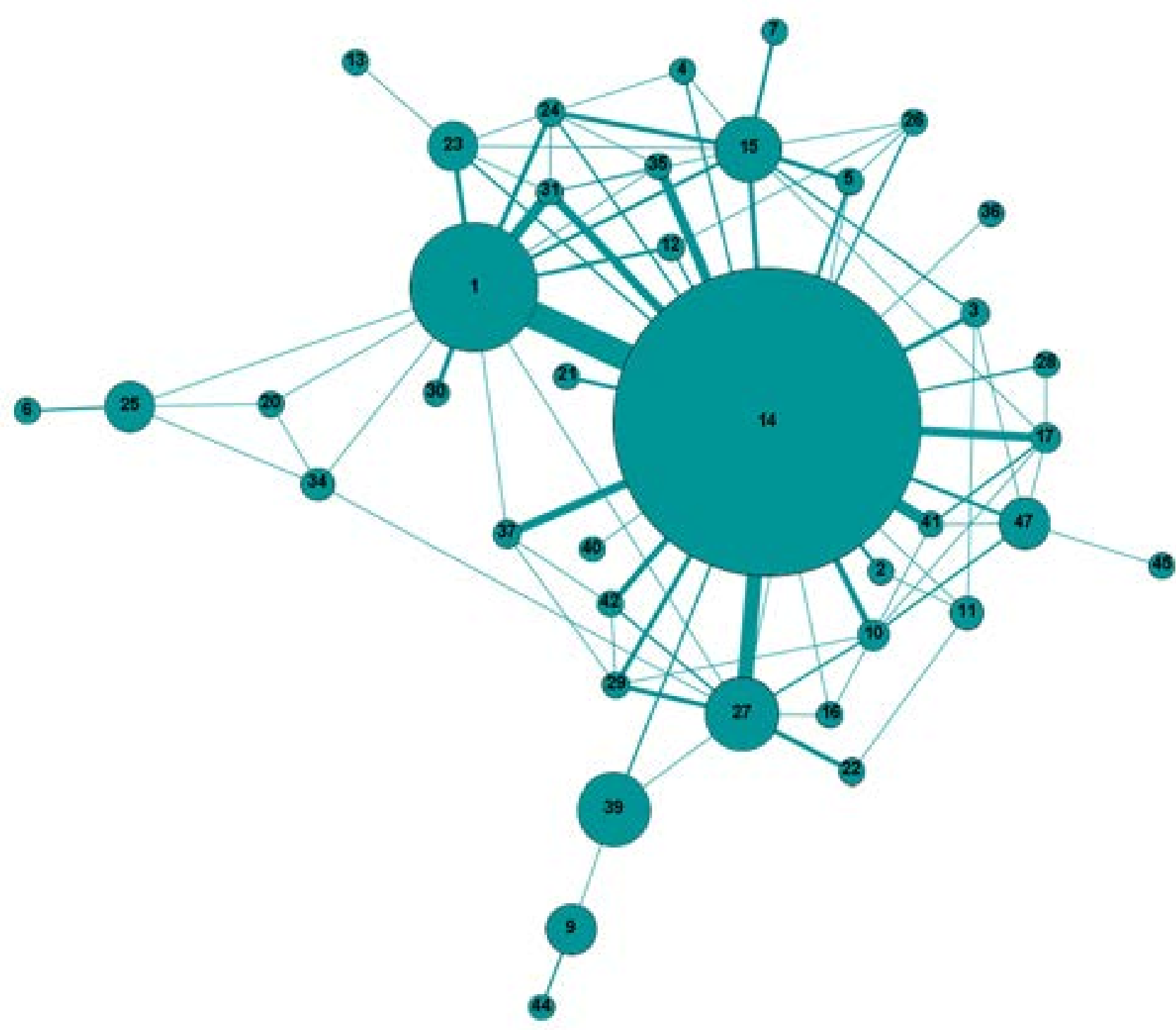

Graphe 1. Les liens entre RT au prisme des communications sur l'art et la culture

Graph 1. Ties between thematic networks

based on papers on art and culture 
isolés, mais le réseau serait également moins dense et les chemins souvent plus longs entre les nœuds. De manière contre-intuitive, le RT14 semble ainsi être moins un lieu autonome d'exercice du métier de sociologue qu'un lieu qui participe à la mise en relation des sociologues entre eux·elles.

Ce constat doit toutefois être nuancé par la prise en compte des boucles, c'est-à-dire des liens reliant un RT à lui-même du fait de communications individuelles multiples dans un même RT, qui échappent à la représentation réticulaire du Graphe 1. Le RT14, avec $26 \%$ de liens dirigés vers lui-même parmi l'ensemble de ses liens, se révèle alors fortement autocentré - quoique ce taux soit significativement inférieur à ceux des GT45 et RT28, et même des RT27 et RT5 ${ }^{15}$ (Tableau 5). II est donc courant de revenir communiquer au RT14 lorsqu'on y a déjà communiqué par le passé. En somme, si le RT14 fait figure d'espace de dialogue entre les communicant'e.s sur l'art et la culture, il n'en est pas moins dans le même temps un espace de relatif entre-soi. On devine ici que le RT14 est bel et bien composé, pour une part, de sociologues de l'art et de la culture pour soi.

15 Si nous disposons de données exhaustives concernant le RT14, les données concernant les autres RT ne sont que partielles (ne sont considérés que les individus ayant communiqué sur l'art et la culture) et ne permettent donc d'évaluer que par approximation leur degré d'entre-soi. Ce dernier est en outre d'autant plus approximatif que les effectifs sur lesquels il est fondé sont réduits, ce qui est le cas pour les GT45 et RT28 en particulier. to be less an autonomous place for exercising the profession of sociologist, and more a venue that connects sociologists to one another.

However, we must qualify these observations by taking into account loops, i.e., ties linking an RT to itself resulting from multiple individual presentations of papers in a single RT, which are not shown in the network display of Graph 1. RT14, with 26 per cent of ties to itself out of the entirety of its ties, is strongly self-centredeven though this ratio is significantly smaller than in GT45 and RT28, and even RT27 and RT5 ${ }^{15}$ (Table 5). Presenting a paper in RT14 when one has already done so in the past is a common occurrence. Overall, while RT14 is a space for dialogue between researchers on art and culture, it remains a relatively closed space. RT14 thus appears to some extent composed of sociologists of art and culture for themselves.

15 While we have exhaustive data at our disposal on RT14, data on other RTs are only partial (as only the individuals who have presented papers on art and culture are considered) and may only yield an approximation of their level of closure, especially as these numbers apply to small populations-in GT45 and RT28, in particular. 
Tableau 5. Circulations circulaires des communicant $\cdot e \cdot s$ sur l'art et la culture

\begin{tabular}{|l|l|c|c|c|c|}
\hline $\begin{array}{l}\text { Sommets } \\
\text { à boucle }\end{array}$ & Intitulé du RT & $\begin{array}{c}\text { Poids* } \\
\text { de la } \\
\text { boucle }\end{array}$ & $\begin{array}{c}\text { Degré** } \\
\text { du } \\
\text { sommet }\end{array}$ & $\begin{array}{c}\text { Degré } \\
\text { pondéré } \\
\text { (dp) du } \\
\text { sommet }\end{array}$ & $\begin{array}{c}\text { Poids } \\
\text { boucle/ } \\
\text { dp (\%) }\end{array}$ \\
\hline GT45 & Sociologie des conflits & 2 & 3 & 3 & $\mathbf{6 6 , 7}$ \\
\hline RT28 & $\begin{array}{l}\text { Recherches en sciences sociales } \\
\text { sur la sexualité }\end{array}$ & 3 & 4 & 6 & $\mathbf{5 0 , 0}$ \\
\hline RT27 & $\begin{array}{l}\text { Sociologie des intellectuels (et de } \\
\text { l'expertise) }\end{array}$ & 13 & 12 & 42 & $\mathbf{3 1 , 0}$ \\
\hline RT5 & Classes, inégalités, fragmentations & 4 & 6 & 13 & $\mathbf{3 0 , 8}$ \\
\hline RT14 & Sociologie des arts et de la culture & 44 & 29 & 169 & $\mathbf{2 6 , 0}$ \\
\hline RT23 & Travail, activités, techniques & 3 & 8 & 13 & $\mathbf{2 3 , 1}$ \\
\hline RT1 & Savoirs, travail et professions & 12 & 15 & 67 & $\mathbf{1 7 , 9}$ \\
\hline RT22 & $\begin{array}{l}\text { Parcours de vie et dynamiques } \\
\text { sociales }\end{array}$ & 1 & 4 & 6 & $\mathbf{1 6 , 7}$ \\
\hline RT35 & Sociologie du monde associatif & 2 & 6 & 13 & $\mathbf{1 5 , 4}$ \\
\hline RT15 & Jeunesse, Âges de vie, Génération & 4 & 13 & 29 & $\mathbf{1 3 , 8}$ \\
\hline RT3 & $\begin{array}{l}\text { Normes, déviances et réactions } \\
\text { sociales }\end{array}$ & 1 & 7 & 10 & $\mathbf{1 0 , 0}$ \\
\hline RT37 & Sociologie des médias & 1 & 6 & 11 & $\mathbf{9 , 1}$ \\
\hline RT10 & Sociologie de la connaissance & 1 & 9 & 14 & $\mathbf{7 , 1}$ \\
\hline RT41 & Corps, technique et société & 1 & 6 & 15 & $\mathbf{6 , 7}$ \\
\hline RT31 & $\begin{array}{l}\text { Sociologie du sport et des activités } \\
\text { physiques }\end{array}$ & 1 & 8 & 21 & $\mathbf{4 , 8}$ \\
\hline
\end{tabular}

*Un·e communicant·e intervenu·e plusieurs fois dans un même RT donne à la boucle du sommet un poids exponentiel suivant le nombre de ses interventions (2 communications dans ce RT $\rightarrow 1$ lien ; $3 \rightarrow 3$ liens ; $4 \rightarrow 6$ liens).

**Les boucles sont ici comptabilisées et comptent chaque fois pour 2 degrés (entrant et sortant). Elles sont également comptabilisées dans les degrés pondérés, à hauteur du poids de la boucle.

En définitive, le RT14 fait bien moins figure de RT hermétique que de RT œecuménique. Autrement dit, il ne s'agit pas d'un souschamp, c'est-à-dire d'un espace autonome, puisque les frontières institutionnelles ne donnent pas lieu à l'existence de véritables frontières sociales, quoiqu'il puisse être le lieu d'élection de
Table 5. Circular circulations of speakers on art and culture

\begin{tabular}{|l|l|l|l|l|l|}
\hline $\begin{array}{l}\text { Looped } \\
\text { nodes }\end{array}$ & Thematic network (RT) & $\begin{array}{l}\text { Loop } \\
\text { weight* }\end{array}$ & $\begin{array}{l}\text { Node } \\
\text { degree**}\end{array}$ & $\begin{array}{l}\text { Node } \\
\text { weighted } \\
\text { degree (wd) }\end{array}$ & $\begin{array}{l}\text { Loop } \\
\text { weight } \\
\text { wd } \\
(\%)\end{array}$ \\
\hline GT45 & Sociology of conflicts & 2 & 3 & 3 & $\mathbf{6 6 . 7}$ \\
\hline RT28 & $\begin{array}{l}\text { Social science research on } \\
\text { sexuality }\end{array}$ & 3 & 4 & 6 & $\mathbf{5 0 . 0}$ \\
\hline RT27 & $\begin{array}{l}\text { Sociology of intellectuals (and } \\
\text { expertise) }\end{array}$ & 13 & 12 & 42 & $\mathbf{3 1 . 0}$ \\
\hline RT5 & $\begin{array}{l}\text { Classes, inequalities, } \\
\text { fragmentations }\end{array}$ & 4 & 6 & 13 & $\mathbf{3 0 . 8}$ \\
\hline RT14 & Sociology of arts and culture & 44 & 29 & 169 & $\mathbf{2 6 . 0}$ \\
\hline RT23 & Work, activities, technologies & 3 & 8 & 13 & $\mathbf{2 3 . 1}$ \\
\hline RT1 & $\begin{array}{l}\text { Knowledge, labour and } \\
\text { occupations }\end{array}$ & 12 & 15 & 67 & $\mathbf{1 7 . 9}$ \\
\hline RT22 & Life courses and social dynamics & 1 & 4 & 6 & $\mathbf{1 6 . 7}$ \\
\hline RT35 & Sociology of the non-profit sector & 2 & 6 & 13 & $\mathbf{1 5 . 4}$ \\
\hline RT15 & $\begin{array}{l}\text { Youth, stages of life and } \\
\text { generation }\end{array}$ & 4 & 13 & 29 & $\mathbf{1 3 . 8}$ \\
\hline RT3 & $\begin{array}{l}\text { Norms, deviances and social } \\
\text { reactions }\end{array}$ & 1 & 7 & 10 & $\mathbf{1 0 . 0}$ \\
\hline RT37 & Sociology of media & 1 & 6 & 11 & $\mathbf{9 . 1}$ \\
\hline RT10 & Sociology of knowledge & 1 & 9 & 14 & $\mathbf{7 . 1}$ \\
\hline RT41 & Body, technology and society & 1 & 6 & 15 & $\mathbf{6 . 7}$ \\
\hline RT31 & $\begin{array}{l}\text { Sociology of sports and physical } \\
\text { activities }\end{array}$ & 1 & 8 & 21 & $\mathbf{4 . 8}$ \\
\hline
\end{tabular}

*A scholar who has presented several papers in the same RT gives the node loop an exponential weight that increases along with the number of papers presented ( 2 papers presented in a given RT $\rightarrow 1$ tie; $3 \rightarrow 3$ ties; $4 \rightarrow 6$ ties).

**Each node loop counts for two degrees (incoming and outgoing). Node loops are also counted in weighted degrees, based on loop weight.

Ultimately, RT14 appears to be an ecumenical network rather than a hermetic one. In other words, it is not a subfield in the sense of an autonomous space, as institutional boundaries do not give way to genuine social boundaries, even though it may be the place of choice of sociologists of art and culture for themselves. We must 
sociologues de l'art et de la culture pour soi. C'est donc ailleurs qu'il faut tester l'existence d'un sous-champ de la sociologie de l'art et de la culture.

\section{Les communicant·e.s sur l'art et la culture comme sous-champ?}

Si on ne peut parler de sous-champ pour qualifier l'espace restreint du RT14, peut-on en parler pour qualifier l'espace élargi des communicant.e.s sur l'art et la culture ? Bien que ces communicantee.s aient en commun de s'adonner objectivement à une même activité, l'analyse de leurs propriétés socio-académiques montre que cette population reste en réalité relativement représentative de l'ensemble des congressistes et n'est donc pas caractérisée par des capitaux spécifiques. En outre, la prise en compte de l'ensemble de leurs communications (et non plus seulement de celles en lien avec l'art et la culture) et de leurs sujets de thèse montre que les communicant.e.s sur l'art et la culture ne sont presque jamais spécialisé·e.s (uniquement) en sociologie de

l'art et de la culture.

\subsection{Des sociologues ordinaires}

II s'agit d'abord d'examiner où les communicant.e.s sur l'art et la culture sont situé e-s dans le champ académique. II apparaît alors que, du point de vue de leur sexe, de leur statut et de leur localisation institutionnelle, ces individus sont des communicant $\cdot e \cdot s$ comme les autres.

Deux méthodes de comparaison sociographique

Notre base de données ayant été constituée à partir des seules communications sur l'art et la culture, une difficulté se pose au moment de déterminer si les communicant.e.s concerné e.s constituent ou non une population spécifique thus turn elsewhere to test the hypothesis of the existence of a subfield of the sociology of art and culture.

\section{Speakers on Art and Culture as a Subfield?}

While we cannot refer to the small space of RT14 as a subfield, can the term apply to describe the wider space of speakers on art and culture? Although these individuals objectively share in the same activity, analysis of socio-academic properties shows that this population remains effectively relatively representative of the overall population of speakers at the congresses and is not characterized by specific capitals. Additionally, an examination of the entirety of their papers (not just those on art and culture) and $\mathrm{PhD}$ topics shows that speakers on art and culture almost never (solely) specialize in the sociology of art and culture.

\subsection{Ordinary Sociologists}

The first step here is to examine the situation of speakers on art and culture within the academic field. In terms of gender, status, and location of institutional affiliation, these individuals do not stand out from the broader population of speakers at the congresses.

Two Sociographical Comparison Methods

That our database contains solely papers on art and culture posed one challenge as we set out to determine whether or not the scholars in question form a distinct population-namely, finding relevant data for comparison 
celle de trouver des données de comparaison pertinentes. Pour les congrès de 2004 et 2006, nous nous fondons sur les articles de Gérard Boudesseul (Boudesseul 2005, 2006) qui fournissent des indications sur les caractéristiques des congressistes dans leur ensemble (sexe, statut, localisation institutionnelle). L'intérêt de ces données est cependant limité, puisqu'elles ont été construites à partir des programmes et donc des déclarations souvent approximatives des communicant·e.s ; au contraire, nos données l'ont été principalement à partir de recherches effectuées sur Internet afin d'avoir accès à des informations plus précises. II est donc difficile de déterminer si les écarts observés entre les deux populations sont des écarts « réels » ou ne sont que le reflet de différences de codage. Le sexe et, dans une moindre mesure, la localisation institutionnelle, sont sans doute des données pour lesquelles ce problème est moindre que pour le statut.

La nécessité de disposer de données comparatives nous a en outre conduit.e.s à coder nous-mêmes l'ensemble des congressistes pour le congrès médian de 2009 selon un nombre restreint d'indicateurs (à savoir ceux retenus par Boudesseul, afin de déterminer le caractère conjoncturel ou durable des écarts observés). II n'était réaliste d'effectuer ce travail de codage ni sur un grand nombre de caractéristiques ni sur l'ensemble des congrès, celui de 2009 comportant à lui seul 1048 communicant·e.s.

C'est en premier lieu au niveau de leur sexe que les communicant $\cdot e \cdot s$ sur l'art et la culture ne se distinguent pas particulièrement de l'ensemble des communicant·e.s. Le Tableau 6 indique en effet des écarts de 6,6 points au maximum, avec un taux de féminisation certes légèrement plus important chez les premier'e.s, mais seulement lors de deux congrès sur trois - si bien qu'on ne peut en conclure que cette thématique est manifestement plus purposes. For the 2004 and 2006 congresses, we drew on papers by Gérard Boudesseul (Boudesseul 2005; 2006), which provide indications of the general characteristics of speakers (gender, status, location of institutional affiliation). Yet these data have limited value for our research in that they are based on programmes, and accordingly on the often-approximate information provided by the speakers themselves, whereas we gathered our data mainly by conducting web searches in order to have more precise information. It is therefore difficult to establish whether the gaps between the two populations are effective or simply a reflection of differences in coding methods. This is most likely less of an issue when it comes to gender, and to a lesser extent location of institutional affiliation, than it is regarding status.

Due to our need for comparative data, we also coded all speakers in the median congress of 2009 ourselves, based on a small set of indicators (those used by Boudesseul, to determine whether the gaps observed were short term or more lasting). It was not realistic to conduct this coding work either on a large set of features or on all congresses $-1,048$ scholars presented papers at the 2009 congress alone.

Gender is the first criterion where speakers on art and culture do not particularly differ from the broader population of congress speakers. Table 6 indicates gaps of 6.6 points at the most, with an admittedly slightly higher proportion of women among the former, but only at two out of three congresses-which makes it impossible to conclude that this is a manifestly more feminine theme. The numbers on the 2011 and 2013 congresses, although 
féminine. Les chiffres de 2011 et 2013 , quoiqu'on ne dispose pas pour ces deux années de données concernant l'ensemble des congressistes, appellent au même constat, avec toujours une courte majorité de femmes qui semble au moins pour partie refléter l'état de la discipline sociologique dans son ensemble : entre 2010 et 2013 , on comptait $50,8 \%$ de femmes parmi les candidat.e.s à la qualification ${ }^{16}$ pour la section 19 (sociologie, démographie) du Conseil national des universités et $55,4 \%$ parmi les qualifié $\cdot e \cdot s$ (Chenu \& Martin 2016). On observe en outre qu'entre 2004 et 2009, la part des femmes parmi les communicant.e.s sur l'art et la culture a augmenté ${ }^{17}$ et qu'il en est de même, et dans des proportions équivalentes ( +7 pts environ), pour la part des femmes tous sujets confondus : non seulement les deux populations ne sont pas sensiblement différentes, mais elles semblent également suivre les mêmes évolutions.

Tableau 6. Répartition sexuée des communicant·e·s

\begin{tabular}{|l|c|c|}
\hline \multirow{2}{*}{ Congrès } & \multicolumn{2}{|c|}{ Part des femmes parmi les communicant·e.s (en \%) } \\
\cline { 2 - 3 } & Sur l'art et la culture & Tous sujets confondus \\
\hline Villetaneuse 2004 & 53,6 & 47 \\
\hline Bordeaux 2006 & 50,6 & 52 \\
\hline Paris 2009 & 60,0 & 54,3 \\
\hline Grenoble 2011 & 57,9 & $\mathrm{NC}$ \\
\hline Nantes 2013 & 56,9 & $\mathrm{NC}$ \\
\hline Moyenne 2004-2009 & 54,7 & 51,1 \\
\hline TOTAL 2004-2013 & 54,2 & $\mathrm{NC}$ \\
\hline
\end{tabular}

16 Les taux de qualification donnent accès à la morphologie de la population des docteur.e.s en sociologie, donc à une population plus large que celle des seul·e.s sociologues en poste et ainsi plus proche de la population des communicante. $\cdot s$ aux congrès.

17 Si on excepte le léger fléchissement de 2006, difficile à interpréter ici. we do not have data on all speakers, call for similar observations, with again a small majority of women which appears to at least partly reflect the state of sociology as a whole: between 2010 and 2013, there were 50.8 per cent of women among the applicants for qualification (eligibility for recruitment as a lecturer) ${ }^{16}$ in the 19th section (Sociology, Demography) of the French Conseil National des Universités and 55.4 per cent among those selected (Chenu \& Martin 2016). Additionally, between 2004 and 2009, the share of women among speakers on art and culture increased ${ }^{17}$; the same applied, in similar proportions (roughly +7 points), for the overall share of women irrespective of theme: not only are the two populations not significantly different, but they also appear to follow the same trends.

Table 6. Gender distribution of speakers

\begin{tabular}{|l|c|c|}
\hline \multirow{2}{*}{ Congress } & \multicolumn{2}{|c|}{ Share of women among the speakers (in \%) } \\
\cline { 2 - 3 } & On art and culture & All themes \\
\hline Villetaneuse 2004 & 53.6 & 47 \\
\hline Bordeaux 2006 & 50.6 & 52 \\
\hline Paris 2009 & 60.0 & 54.3 \\
\hline Grenoble 2011 & 57.9 & NC \\
\hline Nantes 2013 & 56.9 & NC \\
\hline Average 2004-2009 & 54.7 & 51.1 \\
\hline TOTAL 2004-2013 & 54.2 & NC \\
\hline
\end{tabular}

16 Qualification rates give insight into the morphology of the population of sociologists with a $\mathrm{PhD}-\mathrm{a}$ larger population than that of sociologists with a permanent job, and one that has more similarities with the population of congress speakers.

17 Except for a slight drop in 2006, which is difficult to interpret here. 
Pour les seul.e.s sociologues ayant communiqué au RT14, qui réunit par définition des communicant·e-s sur l'art et la culture, les résultats vont dans le même sens. Ce RT n'apparaît pas particulièrement clivé au niveau du sexe, contrairement à d'autres : avec 73 femmes sur un total de 127 communicant.e.s différent.e.s sur la période 2004-2013 (soit un taux de féminisation de $57 \%$ ), et 9 communicantes sur 22 pour l'édition 2006 (soit un taux de masculinisation de $59 \%$ ), le RT14 apparaît bien moins féminin, par exemple, que le RT33 Famille, vie privée, vie publique (85\% de femmes en 2006 [Boudesseul 2006]), et bien moins masculin, par exemple, que le GT32 ${ }^{18}$ Sociologie des systèmes complexes (76 \% d'hommes en 2006 [Boudesseul 2006]).

Les différences entre la population des intervenant·e.s sur l'art et la culture et celle des intervenant.e.s tous sujets confondus apparaissent également peu marquées au niveau du statut

(Tableau 7)
For the population of sociologists who presented papers in RT14, which by definition brings together speakers on art and culture, findings are similar. Unlike other RTs, there does not seem to be a significant gender cleavage: with 73 female speakers out of a total of 127 over the 2004-2013 period (i.e., 57 per cent of women), and 9 out of 22 for the 2006 congress (i.e., 59 per cent of men), RT14 appears far less feminized, for instance, than RT33 on "Family, private life and public life" ( 85 per cent of women in 2006, according to Boudesseul 2006), and far less male-dominated than GT32 ${ }^{18}$ on the "Sociology of complex systems" (76 per cent of men in 2006, according to Boudesseul 2006).

Likewise, the differences in status between the population of speakers on art and culture and the general population of speakers at the congresses appear fairly small (Table 7).

18 Alors intitulé « groupe ad hoc 1 : sociologie des systèmes complexes ».

18 Then called "ad hoc group no.1". 
Tableau 7. Statut des communicant·e·s aux congrès de 2006 et $2009^{19}$

\begin{tabular}{|c|c|c|c|c|}
\hline \multirow[b]{2}{*}{ Statut } & \multicolumn{2}{|c|}{ Communicante.e.s Bordeaux 2006 (en \%) } & \multicolumn{2}{|c|}{$\begin{array}{l}\text { Communicant.e.s } \\
2009 \text { (en \%) }\end{array}$} \\
\hline & $\begin{array}{l}\text { Sur l'art et la } \\
\text { culture }(\mathrm{N}=81)\end{array}$ & $\begin{array}{l}\text { Tous sujets } \\
\text { confondus ( } \mathrm{N}=1345 \text { ) } \\
\text { (Boudesseul 2006) } \\
\end{array}$ & $\begin{array}{l}\text { Sur l'art et } \\
\text { la culture } \\
(\mathrm{N}=65)\end{array}$ & $\begin{array}{l}\text { Tous sujets } \\
\text { confondus } \\
(\mathrm{N}=1048) \\
\end{array}$ \\
\hline Doctorant·e & 35,8 & 31,7 & 41,5 & 35,1 \\
\hline $\begin{array}{l}\text { Docteur } \cdot e^{*} \\
\text { non titulaire }\end{array}$ & 19,8 & 21,6 & 18,5 & 19,8 \\
\hline $\begin{array}{l}\text { Titulaire }^{* *} \\
\text { (MCF, PU, } \\
\text { assimilé) }\end{array}$ & 32,1 & 31,3 & 40,0 & 41,1 \\
\hline Autre $^{\star \star \star}$ & 0,0 & 1,7 & 0,0 & 3,5 \\
\hline Indéterminé & 12,3 & 13,7 & 0,0 & 0,4 \\
\hline TOTAL & 100 & 100 & 100 & 100 \\
\hline
\end{tabular}

*Cette catégorie correspond à celle des « non titulaires de l'enseignement supérieur » chez Boudesseul, qu'il distingue des « doctorants ".

${ }^{* *}$ Cette catégorie rassemble, comme chez Boudesseul, des statuts variés, dont les titulaires à l'étranger, ceux·celles de l'enseignement supérieur privé et les chercheur·e·s en laboratoire privé.

${ }^{* * *}$ Cette catégorie rassemble, s'agissant des données de Boudesseul, des «sociologues d'entreprise » ou « indépendants ». Elle est plus large s'agissant de nos données puisqu'elle regroupe également les ingénieur.e.s d'études et de recherche titulaires, les chargé·e.s de mission, les formateurs/formatrices et les étudiant·e·s non-inscrit e-s en thèse au moment de leur communication.

On peut tout au plus noter une légère surreprésentation des doctorant·e.s chez les communicant.e.s sur l'art et la culture, en 2006 comme en 2009. Quant aux écarts pour les autres catégories de statut, ils sont particulièrement faibles. De plus, entre 2006

19 L'article de Boudesseul sur le congrès de 2004 ne comportant pas de données relatives au statut, la comparaison s'avère impossible pour cette année-là.
Table 7. Status of speakers at the 2006 and 2009 congresses $^{19}$

\begin{tabular}{|c|c|c|c|c|}
\hline \multirow[b]{2}{*}{ Status } & \multicolumn{2}{|c|}{ Bordeaux 2006 speakers (in \%) } & \multicolumn{2}{|c|}{ Paris 2009 speakers (in \%) } \\
\hline & $\begin{array}{l}\text { On art and } \\
\text { culture }(\mathrm{N}=81)\end{array}$ & $\begin{array}{l}\text { All themes } \\
(\mathrm{N}=1345) \\
\text { (Boudesseul 2006) }\end{array}$ & $\begin{array}{l}\text { On art and } \\
\text { culture }(\mathrm{N}=65)\end{array}$ & $\begin{array}{l}\text { All themes } \\
(\mathrm{N}=1048)\end{array}$ \\
\hline $\mathrm{PhD}$ candidate & 35.8 & 31.7 & 41.5 & 35.1 \\
\hline $\begin{array}{l}\mathrm{PhD}^{\star} \\
\text { (no permanent position) }\end{array}$ & 19.8 & 21.6 & 18.5 & 19.8 \\
\hline Permanent position ${ }^{\star *}$ & 32.1 & 31.3 & 40.0 & 41.1 \\
\hline Other $r^{\star \star \star}$ & 0.0 & 1.7 & 0.0 & 3.5 \\
\hline Unknown & 12.3 & 13.7 & 0.0 & 0.4 \\
\hline TOTAL & 100 & 100 & 100 & 100 \\
\hline
\end{tabular}

"This category matches that of the "non-permanent higher education personnel" in Boudesseul's paper; he distinguishes them from "PhD candidates."

${ }^{* *}$ As in Boudesseul's paper, this category includes individuals with varied status, including holders of permanent positions abroad, in private higher education, and researchers in private laboratories.

${ }^{* * *}$ Applied to Boudesseul's data, this category includes corporate and independen sociologists. Applied to our data, it is broader, as it also includes tenured research engineers, project managers, instructors and students who are not PhD candidates at the time of their presentation.

At most, we can observe a slight over-representation of $\mathrm{PhD}$ candidates among the speakers on art and culture both in 2006 and 2009. Gaps pertaining to other status categories are particularly small. Also, between 2006 and 2009, trends in the proportion of the respective status groups systematically converged: the

19 As Boudesseul's paper on the 2004 congress does not include data on status, comparison is impossible for that year. 
et 2009, les évolutions de la part de chacun des groupes de statut se font systématiquement dans le même sens : la part de doctorant $\cdot e \cdot s$ et de titulaires parmi les communicant.e.s sur l'art et la culture augmente tout comme la part de leurs homologues tous sujets confondus ; et si la part de docteur.e.s non titulaires parmi les communicant'e.s sur l'art et la culture diminue entre 2006 et 2009 , c'est également le cas pour l'ensemble des docteur·e·s non

titulaires.

Il est possible de préciser encore ce constat de ressemblance de statut entre les communicant.e.s sur l'art et la culture et l'ensemble des congressistes en s'intéressant aux seul.e.s titulaires de l'enseignement supérieur et de la recherche publics français. Le Tableau 8 montre, pour 2009, une remarquable similarité, que l'on prenne en compte leur rang (A ou B) ou leur lieu d'affectation (université ou institut de recherche tel que le Centre national de la recherche scientifique, l'Institut national d'études démographiques,

etc.) share of PhD candidates and holders of permanent positions among speakers on art and culture increased, as did the share of their counterparts among the broader population of speakers at the congresses. Likewise, the share of $\mathrm{PhD}$ holders without a permanent position decreased between 2006 and 2009 both among the speakers on art and culture and among the broader population of speakers.

The similarity in status of the speakers on art and culture and the overall population of speakers at the congresses can also be observed among the scholars who hold permanent positions in French public higher education and research. For 2009, Table 8 displays a remarkable similarity in terms of rank (A or $B$ ) and institutional affiliation (with a university or a research institute such as the French National Center for Scientific Research [CNRS], or the French National Institute for Demographic Studies [Ined]). 
Tableau 8. Répartition statutaire des communicant $\cdot e \cdot s$ titulaires au congrès de 2009

\begin{tabular}{|l|l|l|}
\hline \multirow{2}{*}{ Statut } & \multicolumn{2}{|l|}{ Paris 2009 } \\
\cline { 2 - 3 } & \multicolumn{2}{|l|}{ Part (en \%) des titulaires communiquant... } \\
\cline { 2 - 3 } & $\begin{array}{l}\text { sur l'art et la culture } \\
(\mathrm{N}=20)\end{array}$ & $\begin{array}{l}\text { sur tous sujets confondus } \\
(\mathrm{N}=355)\end{array}$ \\
\hline Maître·sse de conférences (MCF) & 60,0 & 56,1 \\
\hline Chargé·e de recherche (CR) & 15,0 & 20,6 \\
\hline Professeur·e des universités (PU) & 15,0 & 17,2 \\
\hline Directeur·rice de recherche (DR) & 10,0 & 6,2 \\
\hline Rang B (MCF + CR) & 75,0 & 76,6 \\
\hline Rang A (PU + DR) & 25,0 & 23,4 \\
\hline Universitaires (MCF + PU) & 75,0 & 73,2 \\
\hline Chercheur·e·s (CR + DR) & 25,0 & 26,8 \\
\hline TOTAL & $\mathbf{1 0 0}$ & $\mathbf{1 0 0}$ \\
\hline
\end{tabular}

*En France, un poste de maître-sse de conférences (MCF) correspond plus ou moins à un poste de maître-sse-assistant.e ou de professeur.e assistant.e, à ceci près que les MCF sont titulaires. Les positions académiques y sont divisées en deux rangs : le rang $\mathrm{B}$ requiert un doctorat et inclut les maître-sse-s de conférences et les chargé.e.s de recherche (l'équivalent des premiers dans les instituts de recherche tels que le CNRS ou l'Ined) ; le rang $A$ requiert une habilitation à diriger des recherches (HDR) et inclut les professeur.e.s d'université et les directeur.rice-s de recherche (l'équivalent des premier-e.s dans les instituts de recherche).

Si on se penche enfin sur la localisation de l'institution à laquelle les communicant·e.s étaient rattaché·e.s au moment de communiquer, la comparaison montre ici encore des écarts faibles (Tableau 9). Pour le congrès de 2004, ces écarts sont de 5 points au maximum, avec des communicant·e.s sur l'art et la culture légèrement plus parisien.ne's que les autres. Pour le congrès de 2009, dont les données issues exclusivement de nos codages sont plus fiables, ces écarts sont de 3 points au maximum. Les évolutions observées entre 2004 et 2009 vont en outre dans le même sens, avec
Table 8. Status of speakers in permanent positions at the 2009 congress

\begin{tabular}{|c|c|c|}
\hline \multirow{3}{*}{ Status* } & \multicolumn{2}{|l|}{ Paris 2009} \\
\hline & \multicolumn{2}{|c|}{$\begin{array}{l}\text { Share }(\%) \text { of speakers in permanent positions presenting } \\
\text { a paper... }\end{array}$} \\
\hline & On art and culture $(\mathrm{N}=20)$ & All themes $(\mathrm{N}=355)$ \\
\hline Senior lecturer (MCF) & 60.0 & 56.1 \\
\hline Researcher (CR) & 15.0 & 20.6 \\
\hline Professor (PU) & 15.0 & 17.2 \\
\hline Director of research (DR) & 10.0 & 6.2 \\
\hline Ranked B (MCF + CR) & 75.0 & 76.6 \\
\hline Ranked A (PU + DR) & 25.0 & 23.4 \\
\hline $\begin{array}{l}\text { Faculty members (MCF } \\
+\mathrm{PU})\end{array}$ & 75.0 & 73.2 \\
\hline Researchers (CR + DR) & 25.0 & 26.8 \\
\hline TOTAL & 100 & 100 \\
\hline
\end{tabular}

*In France, a maître de conférences (MCF) position is roughly equivalent to senior lecture or associate professor, except that MCFs have tenure. Academic positions are subdivided into two ranks: rank $\mathrm{B}$ requires a $\mathrm{PhD}$ and includes maîtres de conférences and chargés de recherche (the equivalent in research institutes such as the CNRS or the Ined); rank A requires an habilitation à diriger des recherches (HDR-habilitation to supervise research) and includes professors and directeurs de recherche (the equivalent in research institutes).

Lastly, comparisons of the location of the speakers' institutions of affiliation at the time of their presentation also yield small gaps (Table 9). Regarding the 2004 congress, they do not exceed five points, with slightly more Parisians among speakers on art and culture than in the broader population. Regarding the 2009 congress, for which the data come exclusively from our own coding and are more reliable, they do not exceed three points. Trends observed between 2004 and 2009 converge, with an increase in 
notamment une augmentation de la part des communicantee.s localisé.e.s à l'étranger pour les communicant·e.s sur l'art et la culture comme pour l'ensemble des communicant·e·s.

Tableau 9. Localisation institutionnelle des communicant·e.s aux congrès de 2004 et $2009^{20}$

\begin{tabular}{|l|l|l|l|l|}
\hline \multirow{2}{*}{$\begin{array}{l}\text { Affiliation } \\
\text { institutionnelle }\end{array}$} & \multicolumn{2}{|l|}{$\begin{array}{l}\text { Communicant·e·s Villetaneuse 2004 } \\
\text { (en \%) }\end{array}$} & $\begin{array}{l}\text { Communicant·e·s Paris 2009 } \\
\text { (en \%) }\end{array}$ \\
\cline { 2 - 5 } & culture (N =69) & $\begin{array}{l}\text { Tous sujets } \\
\text { confondus (N =1015) } \\
\text { (Boudesseul 2005) }\end{array}$ & $\begin{array}{l}\text { Sur l'art et la } \\
\text { culture (N =65) }\end{array}$ & $\begin{array}{l}\text { Tous sujets } \\
\text { confondus } \\
(\mathrm{N}=1048)\end{array}$ \\
\hline Île-de-France & 55,1 & 50 & 49,2 & 47,9 \\
\hline Province & 39,1 & 42 & 35,4 & 38,4 \\
\hline Étranger & 5,8 & 6,3 & 15,4 & 13,2 \\
\hline Indéterminée & 0 & 1,7 & 0 & 0,6 \\
\hline TOTAL & $\mathbf{1 0 0}$ & $\mathbf{1 0 0}$ & $\mathbf{1 0 0}$ & $\mathbf{1 0 0}$ \\
\hline
\end{tabular}

À la lecture de ces résultats, on constate que les communicant $\cdot e \cdot s$ sur l'art et la culture, loin d'être spécifiques, sont plutôt à l'image de l'ensemble des congressistes. En d'autres termes, ces individus ne semblent pas positionnés dans un endroit particulier du champ académique, caractérisé par des capitaux spécifiques et une hiérarchie autonome. Ils ne peuvent ainsi pas être considérés comme constituant un espace spécifique - de relégation ou de consécration - selon leur sexe, leur statut ou leur implantation géographique. II ne suffit pas que des recherches traitent d'art et de culture pour faire exister un sous-champ de la sociologie de l'art et de la culture.

20 Nous n'indiquons pas les résultats pour 2006 car les pourcentages de Boudesseul sur la localisation institutionnelle des congressistes sont particulièrement vagues pour ce congrès. the share of foreign speakers both among speakers on art and culture and among the broader population of speakers.

Table 9. Location of institution of affiliation for speakers at the 2004 and 2009 congresses ${ }^{20}$

\begin{tabular}{|l|l|l|l|l|}
\hline \multirow{2}{*}{ Location of institution } & \multicolumn{3}{|l|}{ Villetaneuse 2004 speakers (in \%) } & \multicolumn{2}{l|}{ Paris 2009 speakers (in \%) } \\
\cline { 2 - 5 } & $\begin{array}{l}\text { On art and } \\
\text { culture } \\
(\mathrm{N}=69)\end{array}$ & $\begin{array}{l}\text { All themes }(\mathrm{N}=1015) \\
\text { (Boudesseul 2005) }\end{array}$ & $\begin{array}{l}\text { On art and } \\
\text { culture (N=65) }\end{array}$ & $\begin{array}{l}\text { All themes } \\
(\mathrm{N}=1048)\end{array}$ \\
\hline Paris area & 55.1 & 50 & 49.2 & 47.9 \\
\hline Rest of France & 39.1 & 42 & 35.4 & 38.4 \\
\hline Abroad & 5.8 & 6.3 & 15.4 & 13.2 \\
\hline Unknown & 0 & 1.7 & 0 & 0.6 \\
\hline TOTAL & 100 & 100 & 100 & 100 \\
\hline
\end{tabular}

These results suggest that speakers on art and culture are far from a distinct group, being in fact fairly representative of the entire population of speakers at the congresses. In other words, they do not appear to be positioned at a particular spot in the academic field, characterized by specific capitals and an autonomous hierarchy. Therefore, they cannot be considered to form a specific space-of relegation or consecration-based on gender, status or geographical location. The existence of researchers on art and culture alone is not enough for a subfield of the sociology of art and culture to exist.

20 We do not mention the results on the 2006 congress, as Boudesseul's percentages on the locations of speakers' institutions of affiliation are particularly vague for that edition. 


\subsection{Des sociologues diversifié·e·s}

On aurait par ailleurs tort d'assimiler la population des sociologues étudiée à une population de sociologues spécialisé·e·s, en ce qu'ils-elles s'intéresseraient uniquement à « un ordre spécial de problèmes » (Durkheim 2007 [1893] : 347). Au contraire, communicant·e.s sur l'art et la culture et sociologues de l'art et de

la culture en soi ne se confondent pas.

Si on s'intéresse aux interventions des communicant.e.s sur l'art et la culture n'ayant pas trait à l'art et la culture, on dénombre 101 communicant.e.s sur 349 , soit plus d'un quart d'entre eux.elles $(28,9 \%)$, ayant parlé aux congrès de tout autre chose que d'art et de culture. Encore que ce chiffre comporte un biais : les critères de constitution de notre population font qu'il est impossible pour les communicant·e.s n'étant intervenu·e.s qu'à une seule reprise d'avoir communiqué à propos de tout autre chose que d'art et de culture. En excluant les 175 individus ayant communiqué une seule fois, il apparaît que 58 \% des multicommunicant·e.s ont effectué une communication sur une thématique tout autre que l'art et la culture. Ainsi, non seulement les individus qui communiquent sur l'art et la culture dialoguent-ils entre eux, mais ils dialoguent le plus souvent avec les autres. La division entre spécialités au sein de l'AFS est donc loin de recouper une division entre spécialistes. On comprend que ces sociologues pluriel·le.s, parce qu'ils.elles sont loin de former un monde clos, soient loin d'être hiérarchisé·e·s selon des logiques autonomes.

L'analyse des sujets de thèse (titres ou résumés) offre un constat relativement similaire. Parmi les 332 communicant.e.s sur l'art et la culture pour lesquel.le.s on a retrouvé le titre de la thèse en cours ou réalisée ${ }^{21}$, si 229 (69\%) peuvent être considéré·e·s comme

219 des 17 individus restants n'ont jamais été doctorants (étudiants en M2, chargés d'études, etc.). On ignore s'il en va de même des 8 autres.

\subsection{Versatile Sociologists}

It would be wrong to describe the population of sociologists under study as a population of specialized sociologists, interested only in "a special order of problem" (Durkheim 1960 [1893]: 356). On the contrary, speakers on art and culture and sociologists of art and culture in themselves are separate groups.

There were 101 out of 349 speakers on art and culture who also presented papers on subjects other than art and culture at the congresses, i.e., more than 1 in 4 (28.9 per cent). However, this number is biased in the sense that the criteria for constituting our population make it impossible for speakers who present only one paper to present a paper on something different. If we exclude the 175 individuals who presented only one paper, we find that 58 per cent of speakers who presented several papers did one on something other than art and culture. Thus, not only are speakers on art and culture in dialogue with each other, but they are also often in dialogue with other colleagues. Accordingly, the division between AFS specialities does not overlap with a division between specialists. It might be precisely because they are far from forming a self-enclosed world that these versatile sociologists are not hierarchized according to autonomous logics.

Analysis of speakers' PhD subjects (based on title or abstract) suggests fairly similar observations. Among the 332 speakers on art and culture for whom we were able to find the title of ongoing or completed doctoral research ${ }^{21}, 229$ (69 per cent) could be

21 Nine out of the seventeen remaining individuals were never PhD candidates (master's students, research engineers, etc.). This information is not known 
réalisant ou ayant réalisé un doctorat portant essentiellement sur l'art ou la culture, $97(29,2 \%)$ ont manifestement travaillé sur un autre sujet. De plus, parmi les 229 premier.e.s, seulement 152 $(45,8 \%)$ sont ou étaient inscrit.e.s uniquement en doctorat de sociologie ou assimilé, 7 (2,1\%) sont ou étaient inscrit·e.s dans deux disciplines dont la sociologie et $67\left(20,2 \%{ }^{22}\right)$ uniquement dans une discipline autre que la sociologie. Ainsi, moins de la moitié des individus de notre population effectuent ou ont effectué une thèse en sociologie traitant d'art et de culture ; il n'est finalement besoin ni d'avoir travaillé sur l'art ou la culture pendant son doctorat, ni d'avoir effectué une thèse en sociologie pour parler d'art et de culture aux congrès de l'AFS. En ces circonstances, si spécialisation il y a en sociologie, elle ne semble ni nécessairement précoce, ni nécessairement définitive.

II ressort de cette analyse que les communicant.e.s sur l'art et la culture ne constituent nullement, et pas davantage que les communicantee.s au RT14, un sous-espace autonome au sein de l'espace des congrès. Si cette population ne se distingue pas du reste des sociologues, c'est sans doute parce qu'elle n'est objectivement pas spécialisée ${ }^{23}$. En réalité, seule une partie,

22 On ne dispose pas de la discipline d'inscription de 3 de ces 229 individus

23 Le fait que la sociologie de la culture, en particulier, ne soit pas un domaine réservé à des sociologues spécialisé.e·s n'est peut-être pas sans lien avec son influence sur la discipline sociologique dans son ensemble. La Distinction (Bourdieu 1979), ouvrage de référence largement enseigné et commenté, a ainsi sans doute contribué à légitimer, et donc à multiplier, les recherches dans ce domaine. Selon Stéphane Beaud, la sociologie de la culture légitime a même remplacé - au début des années 2000 - la place occupée dans les années 1960-70 par la sociologie de la classe ouvrière dans le palmarès des objets de recherche prisés par les étudiant.e.s de sociologie d'origine populaire en quête de reconnaissance scolaire et sociale (Beaud 2006 : 469). considered as doing or having completed a $\mathrm{PhD}$ essentially addressing art or culture, but 97 (29.2 per cent) manifestly worked on another object of study. Among the former, only 152 (45.8 per cent) are or were pursuing a PhD in sociology or related disciplines; 7 (2.1 per cent) had two disciplinary affiliations including sociology; and 67 (20.2 per cent $^{22}$ ) had a single disciplinary affiliation other than sociology. Overall, under half of the individuals in our population are doing or have done a sociology $\mathrm{PhD}$ on art and culture; ultimately, one does not need to have worked on art or culture during a $\mathrm{PhD}$ or to have done a $\mathrm{PhD}$ in sociology to speak on art and culture at the AFS congresses. In that context, specializations in sociology, if they occur at all, appear to be neither early nor necessarily permanent.

This analysis shows that, like speakers in RT14, speakers on art and culture in no way form an autonomous sub-space within the space of congresses. The reason this population does not stand out from other sociologist population is probably that it is not objectively specialized $^{23}$. In fact, only a minority among this population can be called specialized -the minority on which we will now focus.

for the eight others.

22 We do not know the disciplinary affiliation for three of these 229 individuals.

23 The fact that the sociology of culture in particular is not the preserve of specialized sociologists might be related to its influence on sociology as a discipline. Bourdieu's famous book Distinction (Bourdieu 1979), which has been widely taught and commented on, probably contributed to legitimizing and boosting research in that area. According to Stéphane Beaud, in the early 2000s, the sociology of legitimate culture even replaced the sociology of the working class at the top of the list of the research subjects sought out by sociology students from working-class backgrounds looking for academic and social recognition (Beaud 2006: 469). 
minoritaire, de cette population peut être caractérisée comme telle.

Dès lors, c'est sur elle qu'il faut porter l'investigation.

\section{Les sociologues de l'art et de la culture en soi et pour soi comme sous-champ?}

On peut en effet identifier, au sein de la population des communicant.e.s sur l'art et la culture, une sous-population de communicant·e.s très spécialisé $\cdot e \cdot s$ dans cette thématique, qui ne se confond ni avec la population du RT14, ni avec celle des communicant·e.s dans leur ensemble. Objectivement spécialisés, la plupart de ces individus s'avèrent également subjectivement spécialisés, au regard de leurs liens institutionnels. Ces sociologues de l'art et de la culture à la fois en soi et pour soi semblent avoir des propriétés spécifiques (proximité aux disciplines et aux champs artistiques et culturels, et position relativement dominée au sein du champ académique) qui suggèrent effectivement une certaine

autonomie.

\subsection{Des sociologues en soi différent $\cdot e \cdot s$}

$\mathrm{Si}$ les communicant.e.s sur l'art et la culture apparaissent globalement plus dispersé.e.s que concentré.e.s, plus en

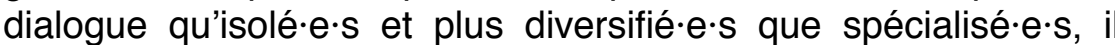
faut nuancer ces constats généraux en distinguant désormais ces communicant.e.s entre eux.elles. II est en effet des sociologues particulièrement spécialisé·e.s parmi eux·elles, et d'autres qui ne le sont pas - ou si peu.

\section{Sociologists of Art and Culture in Themselves and for Themselves as a Subfield?}

Within the population of speakers on art and culture, we were able to identify a sub-population of highly specialized speakers that does not blend either with the population of RT14 or with the overall population of speakers. Most of these objectively specialized individuals are also subjectively specialized regarding their institutional commitments. They are sociologists of art and culture both in themselves and for themselves, and appear to have distinct properties (being close to artistic and cultural disciplines and fields, and somewhat dominated within the academic field) that suggest a degree of autonomy.

\subsection{Different Sociologists in Themselves}

While speakers on art and culture appear to be more scattered between thematic networks than concentrated, more ecumenical than isolated, and more versatile than specialized, these general observations deserve nuancing by differentiating these speakers among themselves. Indeed, this group includes sociologists who are particularly specialized, and others who are not-or practically not. 
La sous-population des sociologues de l'art et de la culture en soi

Parmi les 166 individus de notre population dont on connaît le sujet de thèse et qui ont effectué deux communications ou plus aux congrès, on en dénombre 60 qui consacrent ou ont consacré leur thèse à des questions essentiellement artistiques ou culturelles et ont communiqué exclusivement à propos d'art et de culture ; inversement, 54 consacrent ou ont consacré leur thèse à des questions manifestement autres qu'artistiques et culturelles et ont communiqué au moins une fois à propos d'autre chose que d'art et de culture.

On qualifiera le premier groupe de « en soi » (pour " sociologues de l'art et de la culture en soi ») et le second groupe de «non spécialisé·e·s» (pour « communicant·e·s sur l'art et la culture non spécialisé·e·s »).

Les sociologues de l'art et de la culture en soi se distinguent tant du point de vue de leur proximité aux champs et aux disciplines artistiques et culturels que du point de vue des lieux où ils·elles communiquent. D'une part, ils·elles s'avèrent particulièrement tournéee.s vers l'art et la culture, et pas seulement en tant que terrains de recherche sociologique. Cet intérêt s'observe d'abord, à l'intérieur du champ académique, au travers de leur positionnement disciplinaire. Ils elles ont ainsi fréquemment suivi des études artistiques : si 33 des 177 communicant.e.s sur l'art et la culture (soit 18,6 \%) dont les disciplines d'inscription en DEA ${ }^{24}$ ou seconde année de Master (M2) et en thèse nous sont connues ont été inscrite.es dans une ou plusieurs disciplines artistiques ${ }^{25}$ au cours de ces dernières années d'études, il s'avère que 15 des 43 en soi $(34,9 \%)$ sont concerné.e.s contre aucun'e des non spécialisé·e.s. Inversement, les en soi ont rarement suivi des 24 Diplôme d'études approfondies (DEA).

25 Littérature, histoire de l'art, cinéma, musique, arts du spectacle, sciences des arts, gestion artistique et culturelle ou « arts » sans plus de précision.
The Sub-Population of Sociologists of Art and Culture in Themselves

Among the 166 individuals in our population whose $\mathrm{PhD}$ subject is known and who have presented two or more papers at the congresses, 60 devoted or are devoting their $\mathrm{PhD}$ to essentially artistic or cultural questions and spoke exclusively on art and culture; conversely, 54 devoted or are devoting their $\mathrm{PhD}$ to questions that are manifestly not artistic or cultural, and spoke at least once about something other than art and culture.

We subsequently call the first group "in themselves" (meaning "sociologists of art and culture in themselves") and the second group "non-specialized" (meaning "non specialized speakers on art and culture").

Sociologists of art and culture in themselves stand out both in terms of proximity to artistic fields and disciplines and of the venues in which they presented papers. On the one hand, they appear to be particularly art- and culture-oriented, and not only in the sense that their sociological sites of inquiry are artistic or cultural. Within the academic field, this interest can first be observed by examining their disciplinary positioning. They have frequently completed artistic studies: while 33 out of the 177 speakers on art and culture (i.e., 18.6 per cent), whose master's and $\mathrm{PhD}$ discipline of registration we are aware of, registered in one or several artistic disciplines ${ }^{24}$ during these final years of their higher education, this was the case for 15 out of the 43 in themselves (i.e., 34.9 per cent), but for none of the non-specialized. Conversely, the in themselves rarely graduated in disciplines other than the arts or sociology: 91 out of the 333 speakers (i.e., 27.3 per cent) were or are pursuing

24 Literature, art history, film, music, performing arts, art science, arts management or unspecified "arts." 
études dans d'autres disciplines que les arts ou la sociologie : 91 des 333 communicant.e.s (soit $27,3 \%$ ) sont ou ont été inscrit.e.s en thèse au moins pour partie dans une autre discipline que la sociologie ou les arts, alors que seulement 8 sur 60 des en soi $(13,3 \%)$ sont concerné $\cdot$-s par cette situation. Par conséquent, si la spécialisation en sociologie de l'art et de la culture peut apparaître corrélée à une certaine porosité des frontières disciplinaires, elle est en réalité corrélée uniquement à une porosité à l'égard des disciplines artistiques et non à l'égard des sciences humaines et

sociales.

Leur intérêt pour l'art et la culture s'observe ensuite au travers des activités qu'ils·elles mènent à l'extérieur du champ académique. Une proportion non négligeable des communicantee $s(\mathrm{~N}=58$, soit $16,6 \%$ ) a ainsi rédigé un rapport pour le ministère français de la Culture, parmi lesquel.le.s on trouve 16 des 60 en soi $(26,7 \%)$ et seulement 3 des 54 non spécialisé e.s (5,6\%). Si cette activité est liée, dans la plupart des cas, aux compétences universitaires de leurs auteur.e.s, et peut s'exercer tout en étant universitaire à temps plein, elle manifeste néanmoins une sortie hors du champ académique, puisque les destinataires des études menées se situent dans le champ culturel. En ayant en tête les précautions d'usage lorsqu'on travaille sur de petits effectifs, on peut en outre noter que les en soi semblent exercer un peu plus souvent d'autres activités qui sont a priori beaucoup moins en rapport avec leur position académique : si 62 des 349 communicant.e.s (17,8\%) exercent ou ont exercé au moins une fonction professionnelle dans les champs artistiques et culturels, qu'elle soit artistique $(\mathrm{N}=29)$, administrative $(\mathrm{N}=26)$ ou experte ${ }^{26}(\mathrm{~N}=14)$, les en soi sont 15 sur $60(25 \%)$ dans ce cas, tandis que les non spécialisé·e.s sont

26 Journaliste culturel·le ou chargé·e de mission ou d'études, parfois pour le ministère de la Culture $(\mathrm{N}=4)$. a $\mathrm{PhD}$ at least partly in a discipline other than sociology and the arts, whereas only 8 out of the 60 in themselves (13.3 per cent) were in the same situation. Therefore, where specializations in the sociology of art and culture might appear to be correlated to the permeability of disciplinary boundaries, they are in fact solely correlated to the permeability towards artistic disciplines-not towards the human and social science.

The specific interest in art and culture can also be observed by examining activities outside the academic field. A not altogether insignificant proportion of speakers ( $\mathrm{N}=58$, i.e., 16.6 per cent) had drafted a report for the French Ministry of Culture, including 16 out of the 60 in themselves (26.7 per cent) and only 3 out of the 54 non-specialized (5.6 per cent). While in most cases this experience relates to the academic competencies of their authors, and can occur while they are full-time academics, it reflects a venture out of the academic field, as the recipients of these studies are in the cultural field. Being mindful that cautions apply when discussing small samples, we can also note that the in themselves appear to engage slightly more often in activities that have much less of a relation to their academic position than the reports: while 62 out of the 349 speakers (17.8 per cent) perform or have performed at least one professional function in the artistic and cultural fields, as artists $(\mathrm{N}=29)$, administrative staff $(\mathrm{N}=26)$ or experts ${ }^{25}(\mathrm{~N}=14)$, there were 15 out of 60 in themselves (25 per cent) in this case, as opposed to only 3 out of 54 non-specialized. Thus, it appears

25 Cultural journalists, chargé e.s de mission (task manager) and chargé.e.s d'études (research officer), sometimes for the Ministry of Culture $(\mathrm{N}=4)$ 
seulement 3 sur 54 à être concerné·e·s. L'ouverture sur les champs artistiques et culturels semble donc d'autant plus grande que la fermeture à l'égard des thématiques sociologiques autres que l'art

et la culture est marquée.

D'autre part, l'analyse comparée des circulations entre les différents RT des en soi et des non spécialisé·e.s montre non seulement qu'on ne circule pas dans les mêmes lieux selon son niveau de spécialisation, mais aussi et surtout que les en soi sont, en plus d'être les moins diversifié $\cdot e \cdot s$ dans leurs activités de recherche, les moins dispersé $\cdot e \cdot s$ au sein des congrès et les moins en dialogue avec le reste de la sociologie. En effet, alors que ces individus sont plus nombreux ( $N=60$, contre 54 non spécialisé $\cdot e \cdot s)$, ils n'ont circulé qu'entre 33 RT différents entre 2004 et 2013, quand les autres ont fréquenté $37 \mathrm{RT}$. Au sein même de ces réseaux, ils ont en outre communiqué significativement moins que les non spécialisé $\cdot e \cdot s$ puisque leurs communications n'impliquent que 232 liens, quand les communications réalisées par le deuxième groupe en représentent 356. La comparaison des Graphe 2 et Graphe 3 montre également que le RT14 revêt une importance tout à fait différente selon la population considérée : hormis le fait que le nœud RT14 est au centre géographique du réseau des en soi et aux marges du réseau des non spécialisé·e·s, la représentation proportionnelle de la taille des nœuds en fonction de leur degré pondéré objective le RT14 comme le lieu de communication privilégié des premier.e.s tandis qu'elle montre inversement la maigre importance de ce RT pour les second.e.s. En outre, si le RT14 dispose de trous structuraux dans le premier cas, relian les RT2, RT3, RT11 et RT21 au reste du réseau, il ne dispose que de relations redondantes dans le second. Ainsi, quoique le RT14 ne soit pas fréquenté uniquement par des spécialistes, il en constitue néanmoins un repaire. On devine ce faisant qu'un nombre important de ces sociologues de l'art et de la culture en sol sont, plus encore, des sociologues de l'art et de la culture pour soi, pour lesquels le RT14, en tant qu'instance représentative de cette sociologie, constitue une incontournable référence. that openness to artistic and cultural fields and impermeability to sociological themes other than art and culture are correlated.

Furthermore, comparative analysis of the circulations between thematic networks of sociologists of art and culture in themselves and of non-specialized sociologists shows two results. The first is that sociologists circulate in different venues depending on their degree of specialization; the second-and most important-is that the members of the in themselves group are, in addition to being the least versatile in their research activities, the least scattered at the congresses and the least ecumenical. Indeed, even though there are more of them ( $\mathrm{N}=60$, vs 54 non-specialized), they circulated only between 33 different thematic RTs between 2004 and 2013 (vs 37 RTs for their non specialized counterparts). Within these networks, they presented papers on significantly fewer occasions than the non-specialized, with only 232 ties related to their presentations, vs 356 for the second group. Comparison of Graph 2 and Graph 3 also shows that the importance of RT14 is very different for the two populations: not only is the RT14 node geographically central in the network of the in themselves and peripheral in the network of the non-specialized, but the proportional representation of node size based on weighted degree reveals that RT14 is the venue of choice for the former whereas it is of small significance to the latter. Additionally, while RT14 displays structural holes in the former case, linking RT2, RT3, RT11, and RT21 to the rest of the network, it only displays redundant ties for the latter. Ultimately, while RT14 is not only frequented by specialists, it acts as a haven for them. This suggests that many among these sociologists of art and culture in themselves are also sociologists of art and culture for themselves, for whom RT14, as the representative body of this branch of sociology, is an inevitable reference. 
Graphe 2. Les circulations entre RT des sociologues de l'art et de la culture en soi

Graph 2. Circulation of sociologists of art and culture in themselves between thematic networks

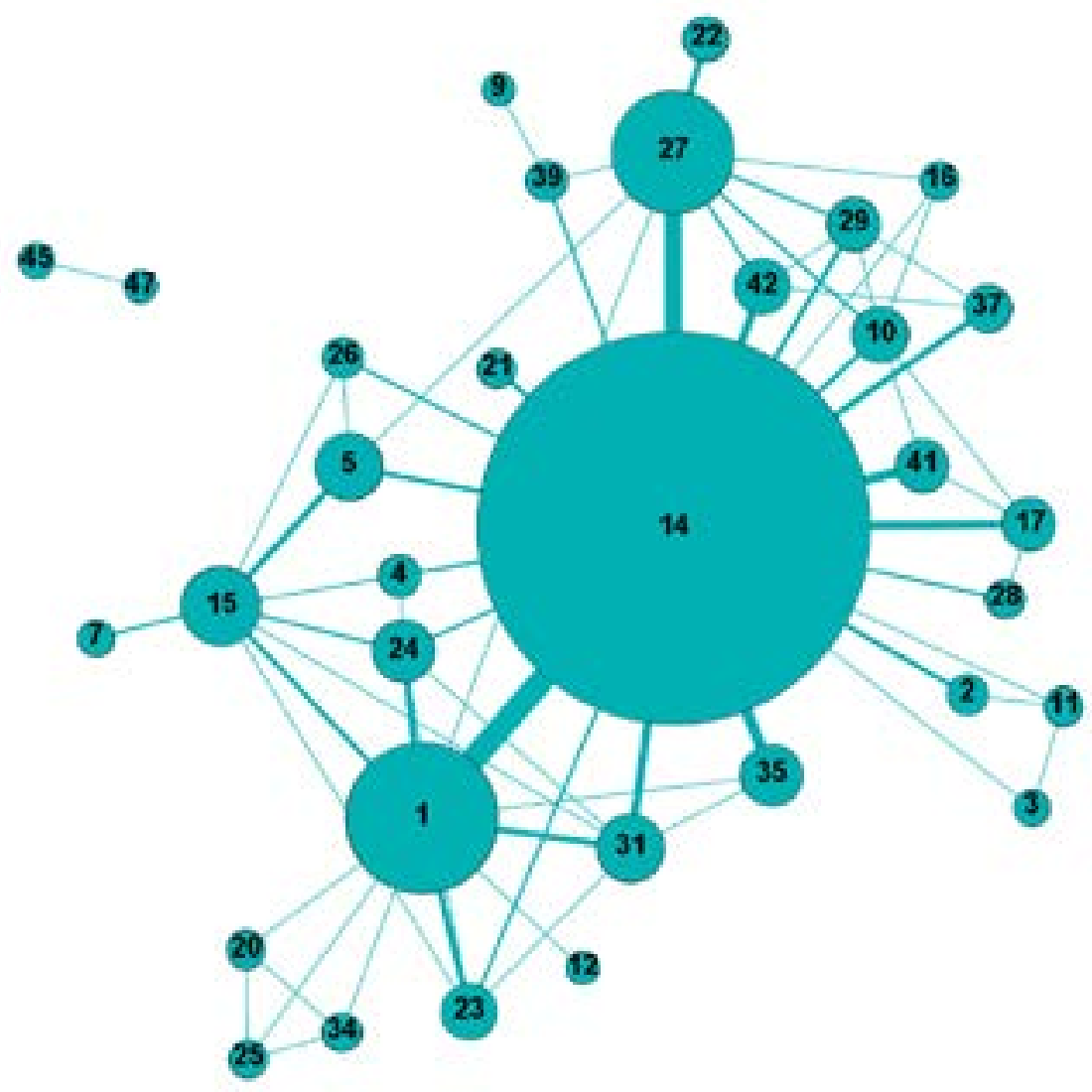

Graphe 3. Les circulations entre RT des communicant·ess Graph 3. Circulation of non-specialized speakers between thematic networks

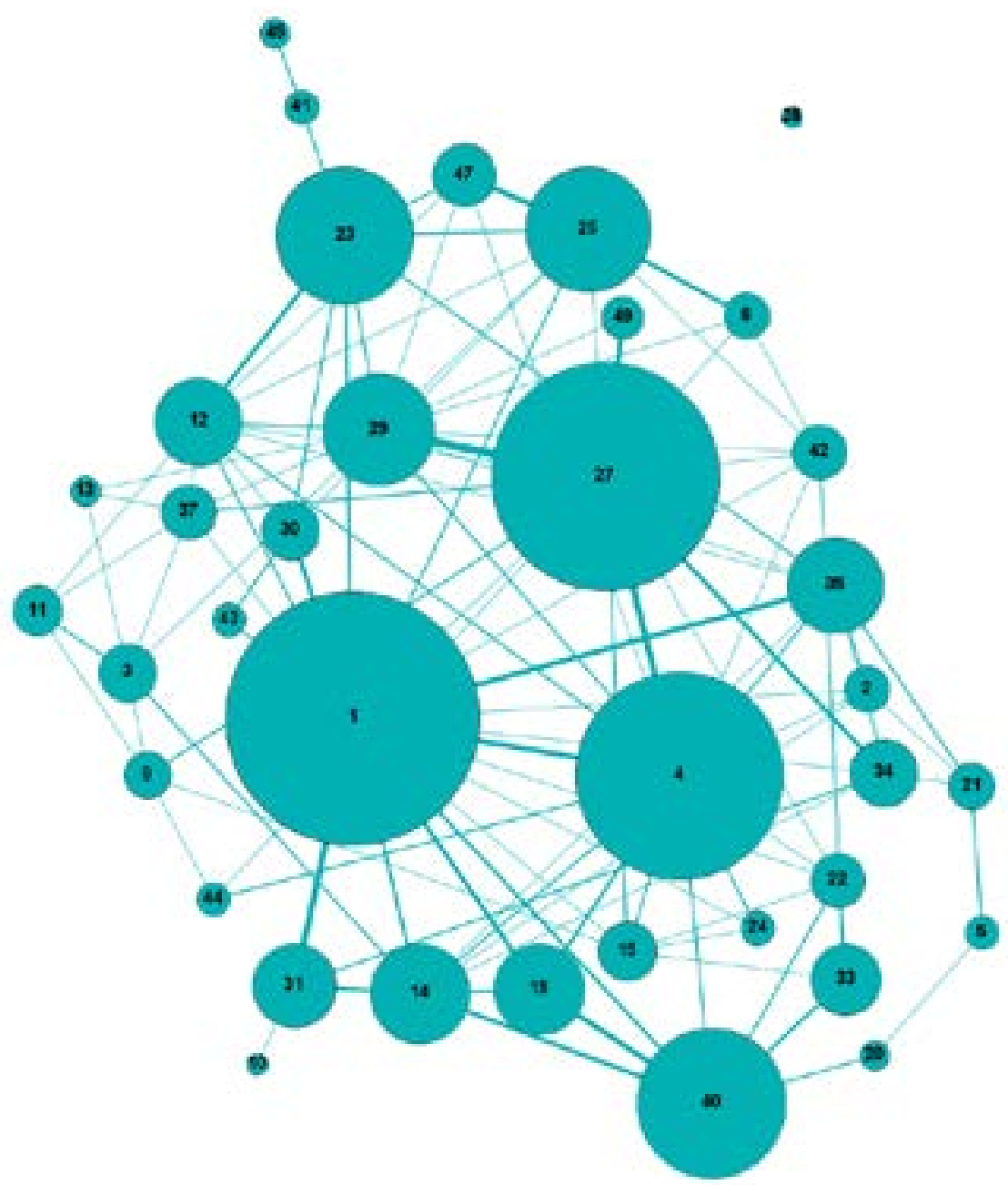


Les plus spécialisé.e.s des communicant·e.s sur l'art et la culture semblent ainsi effectivement présenter des spécificités : relativement éloigné.e.s des autres thématiques sociologiques et des autres sciences humaines et sociales, ils-elles s'avèrent proches des champs et des disciplines artistiques et culturels, et par là même caractérisé.e.s par des centres d'intérêt proprement artistiques et culturels. Une telle spécialisation objective ne suffit toutefois pas à induire l'autonomie : encore faut-il que celle-ci s'accompagne d'une spécialisation subjective.

\subsection{Des sociologues pour soi dominé·e·s}

Pour savoir dans quelle mesure la population des sociologues de l'art et de la culture en soi recoupe celle des sociologues de l'art et de la culture pour soi - c'est-à-dire des chercheur.e.s ayant accepté, à un moment ou un autre de leur parcours, de se voir étiqueté $\cdot \mathrm{e} \cdot \mathrm{s}$ en tant que tel·le·s par des instances représentatives de cette thématique -, nous avons retenu quatre indicateurs d'une forte identification subjective à la sociologie de l'art et de la culture : contribution à la revue Sociologie de l'Art-OPuS, rédaction d'un rapport pour le ministère de la Culture, élection au bureau du RT14, et enfin proportion importante de communications effectuées au

RT14.

La sous-population des sociologues de l'art et de la culture pour soi

Nous qualifions de «pour soi » (pour « sociologues de l'art et de la culture pour soi ») des individus caractérisés par un fort degré d'identification (score égal ou supérieur à 2,5 points), déterminé à partir des variables et selon le barême suivants :
The most specialized speakers on art and culture appear to have distinguishing features: they are relatively far from the other sociological themes and the other human and social science, but close to the artistic and cultural fields and disciplines, and therefore characterized by strictly artistic and cultural areas of interest. Yet this objective specialization does not automatically induce autonomy; it must come with a subjective specialization.

\subsection{Dominated Sociologists for Themselves}

To establish the extent to which the population of sociologists of art and culture in themselves overlaps with that of the sociologists of art and culture for themselves-i.e., researchers who agreed at a given point in their trajectory to be labelled as such by representative bodies of the sociology of art and culture-we selected four indicators of a strong subjective identification with the sociology of art and culture: contributed to the French journal Sociologie de l'Art-OPuS; drafted a report for the French Ministry of Culture; elected to sit on the RT14 board; presented a high proportion of papers at RT14.

The sub-population of sociologists of art and culture for themselves

We call individuals characterized by a strong degree of identification (scoring 2.5 points or higher) "for themselves" (meaning "sociologists of art and culture for themselves"), determined by the following variables and attributing the following number of points: 
1. Contribution à Sociologie de l'Art-OPuS

- 1 article ou édito : 1 pt ( $N=41$, soit $11,7 \%$ des communicant $\cdot e \cdot s$ sur l'art et la culture)

- 2 contributions ou plus : 2 pts $(N=22 \text {, soit } 6,3 \%)^{28}$

2. Avoir rédigé un rapport pour le ministère de la Culture : 2 pts ( $N=58$, soit $16,6 \%)$

3. Avoir été membre du bureau du RT14 : 2 pts ( $N=32$ soit 9,2\%)

4. Avoir communiqué au RT14...

exclusivement, si une seule communication à l'AFS : 1 pt $(N=75$, soit $21,5 \%)$

..la première fois, si 2 communications : 1 pt $(N=2$, soit $0,6 \%$ )

notamment, si 2 communications la même année : 0,5 pt $(N=6$, soit $1,7 \%)$

..exclusivement, si 2 communications : 2 pts $(N=7$, soit $2 \%$ )

...pour une majorité relative de ses communications, $\mathrm{s}$ plus de 2 communications : 2 pts ( $N=18$, soit $5,2 \%)$

C'est au moment du travail de codage qu'est apprécié le degré d'identification à la sociologie de l'art et de la culture. Le seuil de 2,5 points a été retenu car il suppose de cumuler au moins deux indicateurs différents et parce qu'il est supérieur au score moyen des individus n'ayant pas obtenu zéro point (cette moyenne étant de 2,45 ).

Finalement, les pour soi représentent 65 des 349 communicant.e.s sur l'art et la culture (soit 18,6 \%), tandis que 188 ne sont concerné.e.s par aucun de nos indicateurs d'identification (soit 53,9\%).

27 Créée en 1992 sous le nom Sociologie de l'Art, la revue est publiée depuis 2002 sous le titre Sociologie de l'Art-OPuS.

28 La réitération de l'expérience de publication nous paraissant en elle-même significative, nous n'avons distingué que ces deux situations.
1. Contributed to Sociologie de l'Art-OPuS

- 1 paper or editorial: 1 pt ( $N=41$, i.e., $11.7 \%$ of speakers on art and culture)

- 2 contributions or more: 2 pts $(N=22 \text {, i.e., } 6.3 \%)^{27}$

2. Drafted a report for the Ministry of Culture: 2 pts $(N=58$, i.e., $16.6 \%)$

3. Elected to sit on the RT14 board: 2 pts ( $N=32$, i.e., $9.2 \%)$

4. Presented papers at RT14.

..exclusively, if only one paper presented at a congress: 1 pt ( $N=75$, i.e., $21.5 \%)$

the first time, if two papers presented: 1 pt $(N=2$, i.e., $0.6 \%$

in part, if two papers presented the same year: $0.5 \mathrm{pt}$ $(N=6$, i.e., $1.7 \%)$

..exclusively, if two papers: 2 pts $(N=7$, i.e., $2 \%)$

.. a relative majority of the speaker's papers, if more than two papers presented: 2 pts ( $N=18$, i.e., $5.2 \%)$

We assessed the degree of identification with the sociology of art and culture during the coding process. We picked the threshold of 2.5 points because it requires combining at least two indicators and because it is higher than the average of points obtained by the individuals who did not get zero points (2.45).

Ultimately, the in themselves are 65 of the 349 speakers on art and culture (i.e., 18.6\%); 188 speakers are concerned by neither of our indicators of identification (i.e., 53.9\%).

26 Created in 1992 under the name Sociologie de l'Art, the journal has been published as Sociologie de l'Art-OPuS since 2002.

27 We considered the fact that these sociologists had published more than once significant enough in itself to only make a distinction between these two cases. 
Spécialisation objective et subjective vont largement de pair, puisque les pour soi se trouvent être quasi exclusivement des en soi. Néanmoins, en soi et pour soi ne sont pas parfaitement confondu.e.s - puisque sur 44 sociologues objectivement très spécialisé·e·s, 18 ne le sont pas subjectivement (Tableau 10)

Tableau 10. Sociologues de l'art et de la culture en soi et/ou pour soi ${ }^{29}$

\begin{tabular}{|l|l|l|l|l|l|l|}
\hline \multirow{3}{*}{$\begin{array}{l}\text { Sociologues de l'art } \\
\text { et de la culture pour soi }\end{array}$} & \multicolumn{9}{|l|}{ Sociologues de l'art et de la culture en soi } & \multicolumn{2}{l|}{ TOTAL } \\
\cline { 2 - 6 } & OUI & \multicolumn{2}{l|}{ NON } & \multicolumn{2}{l|}{} \\
\cline { 2 - 6 } & Effectifs & $\%$ & Effectifs & $\%$ & Effectifs & $\%$ \\
\hline OUI & 26 & 96,3 & 1 & 3,7 & 27 & 100 \\
\hline NON & 18 & 28,6 & 45 & 71,4 & 63 & 100 \\
\hline TOTAL & 44 & 48,9 & 46 & 51,1 & 90 & 100 \\
\hline
\end{tabular}

Lecture : sur 90 individus, on en dénombre 26 qui peuvent être qualifiés de sociologues de l'art et de la culture à la fois pour soi et en soi, soit $96,3 \%$ des pour soi.

Intéressons-nous à présent aux seul·e·s sociologues de l'art et de la culture à la fois en soi et pour soi $(\mathrm{N}=26)$, afin de déterminer si cette sous-population présente des propriétés distinctives qui pourraient être révélatrices de son autonomie. Si la faiblesse des effectifs de cette sous-population oblige à n'avancer les résultats qui suivent qu'avec prudence, un faisceau d'indices permet néanmoins de formuler l'hypothèse d'une population relativement dominée dans le champ académique. On observe tout d'abord une surreprésentation marquée des femmes chez ces sociologues

29 L'effectif total est bien inférieur à 349 car ne figurent dans ce tableau que les communicant.e.s dont on a pu déterminer le degré de spécialisation objective ( $N=114$ ) et qui ne sont pas, dans le même temps, dans le niveau intermédiaire du degré de spécialisation subjective, ni « OUI », ni « NON » $(\mathrm{N}=24)$.
Objective and subjective specialization largely go hand in hand, as the for themselves are almost exclusively in themselves. However, in themselves and for themselves do not entirely overlap-out of forty-four objectively highly specialized sociologists, eighteen are not subjectively specialized (Table 10).

Table 10. Sociologists of art and culture in themselves and/or for themselves ${ }^{28}$

\begin{tabular}{|c|c|c|c|c|c|c|}
\hline \multirow{3}{*}{$\begin{array}{l}\text { Sociologists of } \\
\text { art and culture for } \\
\text { themselves }\end{array}$} & \multicolumn{4}{|c|}{ Sociologists of art and culture in themselves } & \multirow{2}{*}{\multicolumn{2}{|c|}{ TOTAL }} \\
\hline & \multicolumn{2}{|l|}{ YES } & \multicolumn{2}{|l|}{ NO } & & \\
\hline & Number & $\%$ & Number & $\%$ & Number & $\%$ \\
\hline YES & 26 & 96.3 & 1 & 3.7 & 27 & 100 \\
\hline NO & 18 & 28.6 & 45 & 71.4 & 63 & 100 \\
\hline TOTAL & 44 & 48.9 & 46 & 51.1 & 90 & 100 \\
\hline
\end{tabular}

How to read this table: out of 90 individuals, 26 can be called sociologists of art and culture both for themselves and in themselves, i.e., $96.3 \%$ of sociologists for themselves.

We will now examine the sociologists of art and culture both in themselves and for themselves $(\mathrm{N}=26)$ in order to establish whether this sub-population has distinctive features that could attest to its autonomy. Due to the small number of individuals in this subpopulation, the following findings must be taken with the requisite caution. However, there are indications that this population is relatively dominated within the academic field. First, we observed a marked over-representation of women among these sociologists (65.4 per cent, vs 54.2 per cent of all speakers on art and culture). We also noted (Table 11) that their academic trajectory is more

28 The total number of speakers is below 349 because this table only includes speakers whose degree of objective specialization we were able to establish $(\mathrm{N}=114)$ and who are not at the intermediate degree of subjective specialization - neither YES nor $\mathrm{NO}(\mathrm{N}=24)$. 
$(65,4 \%$, contre $54,2 \%$, comme on l'a vu, pour l'ensemble des communicant.e.s sur l'art et la culture). On note aussi (Tableau 11) qu'ils elles ont un parcours académique plus souvent provincial (que ce soit au niveau du lieu d'obtention de leur DEA/M2, de leur thèse ou de leur premier poste de titulaire), moins prestigieux (les études en grande école parisienne ${ }^{30}$ se font plus rares chez ces individus), mais également plus lent (le temps d'attente entre la soutenance de thèse et l'obtention du premier poste de titulaire étant généralement plus long). often regional (this is suggested by the place where they received their master's degree, completed their $\mathrm{PhD}$ and secured their first permanent posting), less prestigious (with lower proportions having studied in the coveted top Parisian schools ${ }^{29}$ ), and slower (their waiting time between $\mathrm{PhD}$ defence and securing their first permanent posting being generally longer).

29 École normale supérieure, rue d'Ulm (ENS), École normale supérieure Cachan (ENS Cachan), École des hautes études commerciales, Paris (HEC), École des hautes études en sciences sociales (EHESS), Université Paris-Dauphine and Institut d'études politiques, Paris (Sciences Po).
École normale supérieure déla rue d'Ulm (ENS), École normale supérieure (HEC), École des hautes études en sciences sociales (EHESS), Université Paris-Dauphine et Institut d'études politiques de Paris (Sciences Po). 
Tableau 11. Parcours académique des communicant·e·s sur l'art et la culture ${ }^{31}$

\begin{tabular}{|l|c|c|c|}
\hline & $\begin{array}{c}\text { Effectifs } \\
\text { concernés }\end{array}$ & $\begin{array}{c}\text { Effectifs } \\
\text { totaux }\end{array}$ & \% indicatifs \\
\hline DEA/M2 en province & $\mathbf{6 7}$ & $\mathbf{1 6 6}$ & $\mathbf{4 0 , 4}$ \\
\hline En soi et pour soi & 12 & 23 & 52,2 \\
\hline Autres communicant·e·s & 55 & 143 & 38,5 \\
\hline DEA/M2 dans une grande école parisienne & $\mathbf{4 8}$ & $\mathbf{1 6 6}$ & $\mathbf{2 8 , 9}$ \\
\hline En soi et pour soi & 5 & 23 & 21,7 \\
\hline Autres communicant·e·s & 43 & 143 & 30,1 \\
\hline Thèse en province & $\mathbf{1 0 9}$ & $\mathbf{3 0 8}$ & $\mathbf{3 5 , 4}$ \\
\hline En soi et pour soi & 11 & 25 & 44,0 \\
\hline Autres communicant·e·s & 98 & 283 & 34,6 \\
\hline 4 ans et plus avant l'obtention du 1 ${ }^{\text {er }}$ poste & $\mathbf{4 2}$ & $\mathbf{1 2 2}$ & $\mathbf{3 4 , 4}$ \\
\hline En soi et pour soi & 6 & 15 & 40,0 \\
\hline Autres communicant·e·s & 36 & 107 & 33,6 \\
\hline Obtention du 1'r poste en province & $\mathbf{9 4}$ & $\mathbf{1 6 9}$ & $\mathbf{5 5 , 6}$ \\
\hline En soi et pour soi & 12 & 18 & 66,7 \\
\hline Autres communicant·e·s & 82 & 151 & 54,3 \\
\hline
\end{tabular}

Lecture : 67 des 166 communicante.es ont obtenu leur DEA/M2 dans un établissement de province, soit $40,4 \%$. Si on ne considère parmi ces individus que les 23 en soi et pour soi, ils sont 12 dans ce cas, soit $52,2 \%$, alors que les autres communicant.e.s sur l'art et la culture sont 55 sur 143 à être concerné·e·s, soit $38,5 \%$.

Comme les sociologues de l'art et de la culture pour soi se trouvent être aussi, à une exception près, des sociologues de l'art et de la culture en soi, un retour sur les indicateurs de la spécialisation subjective permet de comprendre ces résultats relatifs au

31 Sont exclus ici les individus pour lesquels l'information n'était pas disponible et, pour les quatre variables de localisation institutionnelle, ceux concernés par un parcours à l'étranger.
Table 11. Academic trajectory of speakers on art and culture ${ }^{30}$

\begin{tabular}{|l|c|c|c|}
\hline & $\begin{array}{c}\text { Speakers for whom } \\
\text { the variable applies }\end{array}$ & $\begin{array}{c}\text { All } \\
\text { speakers }\end{array}$ & $\begin{array}{c}\% \\
\text { (indicative) }\end{array}$ \\
\hline Master's outside of Paris region & $\mathbf{6 7}$ & $\mathbf{1 6 6}$ & $\mathbf{4 0 . 4}$ \\
\hline In themselves and for themselves & 12 & 23 & 52.2 \\
\hline Other speakers & 55 & 143 & 38.5 \\
\hline Master's in a prestigious Parisian school & $\mathbf{4 8}$ & $\mathbf{1 6 6}$ & $\mathbf{2 8 . 9}$ \\
\hline In themselves and for themselves & 5 & 23 & 21.7 \\
\hline Other speakers & 43 & 143 & 30.1 \\
\hline PhD outside of Paris region & $\mathbf{1 0 9}$ & $\mathbf{3 0 8}$ & $\mathbf{3 5 . 4}$ \\
\hline In themselves and for themselves & 11 & 25 & 44.0 \\
\hline Other speakers & 98 & 283 & 34.6 \\
\hline 4 years or more before first post & $\mathbf{4 2}$ & $\mathbf{1 2 2}$ & $\mathbf{3 4 . 4}$ \\
\hline In themselves and for themselves & 6 & 15 & 40.0 \\
\hline Other speakers & 36 & 107 & 33.6 \\
\hline First post outside of Paris region & $\mathbf{9 4}$ & $\mathbf{1 6 9}$ & $\mathbf{5 5 . 6}$ \\
\hline In themselves and for themselves & 12 & 18 & 66.7 \\
\hline Other speakers & 82 & 151 & 54.3 \\
\hline
\end{tabular}

How to read this table: 67 out of the 166 speakers on art and culture did their master's degree outside the Paris region, i.e. $40.4 \%$. If we only consider the 23 sociologists in themselves and for themselves among them, 12 are in the same situation, i.e., $52.2 \%$; this applies to 55 out of the 143 other speakers on art and culture, i.e., $38.5 \%$.

As the sociologists of art and culture for themselves also happen to be-with one exception-sociologists of art and culture in themselves, an examination of the indicators of subjective specialization sheds light on these findings pertaining to academic trajectory. Indeed, agreeing to be identified as a sociologist of art

30 This table excludes individuals for whom information was unavailable and regarding the four variables on location, those with careers abroad. 
parcours académique. En effet, accepter d'être identifié·e comme sociologue de l'art et de la culture, c'est exister dans des instances qui n'occupent pas une position académique dominante. Ainsi, la revue Sociologie de l'Art-OPuS ne figure pas parmi les revues les mieux classées par l'AERES en juillet $2008^{32}$. En tant qu'elle manifeste une sortie partielle hors du champ académique, la rédaction d'un rapport pour le ministère de la Culture constitue quant à elle une publication de moindre poids académique qu'un article de revue scientifique. Le RT14 lui-même, enfin, n'occupe pas une position dominante, comme en témoigne la comparaison de la composition de son bureau avec celle du bureau des deux autres RT où interviennent principalement les communicant·e.s sur l'art et la culture, à savoir le RT1 (travail) et le RT27 (intellectuels), ainsi qu'avec celle du bureau du RT4 (éducation), pour lequel on dispose de données plus fiables et comparables dans le temps et qui est en outre, derrière le RT1, le plus gros RT de l'AFS en termes de nombre de communications accueillies entre 2004 et 2013 (Tableau 12) $^{33}$.

32 L'Agence d'évaluation de la recherche et de l'enseignement supérieur (20062013) a établi des listes par discipline des revues scientifiques, hiérarchisées en catégories $(A>B>C)$. En sociologie/démographie, Sociologie de l'ArtOPuS y était classée « $B$ » et non « $A$ ». II ne s'agit pas de souscrire à ce classement qui a fait l'objet de nombreuses critiques, mais de le considérer comme un indicateur, à un moment donné, de la valeur académique accordée à cette revue.

33 Nous remercions Stéphane Bonnéry, co-responsable du RT4 de 2013 à 2017 et contributeur du présent numéro, de nous avoir transmis les informations concernant le bureau de ce RT depuis 2013. Les données concernant les RT1 et RT27 proviennent des sites web des RT et de leur page sur le site de l'AFS. Nous ne disposons pas de la composition des bureaux antérieure 2013, sauf pour le RT14; pour cette raison, la comparaison est ici effectuée avec une période postérieure (2015-2017), qui sort de la période étudiée. and culture means existing in bodies whose academic position is not dominant. Sociologie de l'Art-OPuS was for instance not among the top journals in the rankings published by the government evaluation agency AERES in July $2008^{31}$. As it manifests a partial exit from the academic field, the drafting of a report for the Ministry of Culture leads to a publication whose academic weight is lower than that of a paper in a scientific journal. Lastly, RT14 itself does not hold a dominant position either, which we see if we compare the composition of its board with the boards of two other networks where speakers on art and culture often present papers-RT1 (labour) and RT27 (intellectuals) - and with the board of RT4 (education), for which the data at our disposal are more reliable and more comparable across time, and which is among the biggest AFS thematic networks in terms of papers presented between 2004 and $2013^{32}$, second only to RT1 (Table 12).

31 The Agence d'évaluation de la recherche et de l'enseignement supérieur (2006-2013) published lists of scientific journals by discipline, hierarchized into categories $(A>B>C)$. In sociology/demography, Sociologie de l'Art-OPuS was ranked $\mathrm{B}$. We do not endorse this ranking, which has attracted much criticism, but consider it as an indicator of the academic value assigned to this journal at that specific point in time.

32 We thank Stéphane Bonnéry, co-head of RT4 from 2013 to 2017 and fellow contributor to this issue, for passing on information regarding the board of that RT since 2013. Data on RT1 and RT27 were collected from the websites of those networks and their pages on the AFS website. We do not have data on the composition of boards before 2013, except for RT14; for that reason, we performed a comparison here on a subsequent period (20152017), which is beyond the scope of the period under study. 
Tableau 12. Composition des bureaux du RT14, du RT1, du RT4 et du RT27 (2013 et 2015)

\begin{tabular}{|l|l|l|l|l|l|l|l|}
\hline \multirow{2}{*}{$\begin{array}{l}\text { Sexe et statut } \\
\text { des membres }\end{array}$} & \multicolumn{2}{|l|}{$2013-2015$} & \multicolumn{2}{l|}{ 2015-2017 } \\
\cline { 2 - 10 } & RT14 & RT4 & RT27 & RT14 & RT1 & RT4 & RT27 \\
\hline Femme & 9 & 12 & 2 & 7 & 3 & 16 & 2 \\
\hline Homme & 2 & 6 & 9 & 5 & 9 & 6 & 8 \\
\hline Doctorant·e & 4 & 0 & 3 & 4 & 2 & 1 & 3 \\
\hline Docteur·e sans poste & 4 & 2 & 2 & 5 & 2 & 4 & 1 \\
\hline MCF ou CR & 3 & 10 & 3 & 3 & 4 & 12 & 6 \\
\hline PU ou DR & 0 & 6 & 3 & 0 & 4 & 5 & 0 \\
\hline Effectif total du bureau & 11 & 18 & 11 & 12 & 12 & 22 & 10 \\
\hline
\end{tabular}

Le bureau du RT14 élu en 2013 comptait ainsi plus de $80 \%$ de femmes (contre deux tiers au RT4 et moins d'une sur cinq au RT27) et moins d'un tiers de titulaires (qui plus est tou'te's de rang B), alors que la majorité des membres du bureau du RT27, et plus encore du RT4, étaient titulaires, avec une représentation non négligeable des rangs $A$. On peut aussi souligner l'absence de doctorant.e.s au bureau du RT4 alors que ces dernier.e.s font partie, avec les docteur.e-s sans poste, des catégories les plus représentées dans celui du RT14. L'analyse des bureaux élus en 2015 fait apparaître également une plus forte représentation de femmes au RT14 qu'aux RT1 et RT27, une proportion de doctorant.e.s plus importante et de titulaires de rang $A$ plus faible au RT14 qu'aux RT1 et RT4 et une moindre part des titulaires au

RT14 que dans les trois autres RT.

Les en soi et pour soi semblent donc présenter plusieurs particularités : en position relativement dominée dans le champ
Table 12. Composition of the board in thematic networks RT14, RT1, RT4 and RT27 (2013 and 2015)

\begin{tabular}{|l|l|l|l|l|l|l|l|}
\hline \multirow{2}{*}{ Gender and status of members } & \multicolumn{2}{|l|}{$2013-2015$} & \multicolumn{2}{l|}{$2015-2017$} \\
\cline { 2 - 9 } & RT14 & RT4 & RT27 & RT14 & RT1 & RT4 & RT27 \\
\hline Woman & 9 & 12 & 2 & 7 & 3 & 16 & 2 \\
\hline Man & 2 & 6 & 9 & 5 & 9 & 6 & 8 \\
\hline PhD candidate & 4 & 0 & 3 & 4 & 2 & 1 & 3 \\
\hline PhD (no permanent job) & 4 & 2 & 2 & 5 & 2 & 4 & 1 \\
\hline Senior lecturer/Researcher & 3 & 10 & 3 & 3 & 4 & 12 & 6 \\
\hline Professor/Dir. of research & 0 & 6 & 3 & 0 & 4 & 5 & 0 \\
\hline Total no. board members & 11 & 18 & 11 & 12 & 12 & 22 & 10 \\
\hline
\end{tabular}

The RT14 board elected in 2013 included more than 80 per cent of women ( vs two thirds in RT4 and less than one in five in RT27) and under a third of holders of permanent positions (all ranked B), whereas the majority of board members in RT27, and to an even greater degree in RT4, had permanent positions, and featured a significant number of A-ranked academics. We also noted the absence of PhD candidates on the RT4 board, even though they constitute one of the best-represented categories on the RT14 board, along with $\mathrm{PhD}$ holders without a permanent position. Analysis of the boards elected in 2015 also reveals that women are more represented in RT14 than in RT1 and RT27, PhD candidates are found in higher proportions and A-ranked academics in permanent positions in lower proportions in RT14 than in RT1 and RT4, and the share of academics in permanent positions is smaller in RT14 than in the three other networks.

The in themselves and for themselves appear to share several distinguishing features: they occupy a relatively dominated position 
académique $^{34}$, tant du point de vue du sexe que du parcours institutionnel, caractérisé.e.s en outre par une proximité aux champs et aux disciplines artistiques et culturels assimilable à un capital spécifique, ils·elles semblent bel et bien appartenir à un espace " qui, bien que hiérarchis[é], offr[e une] hiérarchi[e] autonom[e] "

(Bourdieu 2012 : 33). Peut-on parler dès lors de sous-champ des sociologues de l'art et de la culture en soi et pour soi ?

L'étude de leurs jurys de thèse ne permet toutefois pas de valider pleinementl'hypothèse initiale d'un espace véritablementautonome. Inspirée des recherches d'Olivier Godechot (Godechot 2013), l'analyse de réseaux appliquée au cas des relations de coprésence dans les jurys de thèse des communicant.e.s sur l'art et la culture montre en effet que les sociologues de l'art et de la culture en soi et pour soi ne sont finalement pas si singulier.e.s au sein du champ sociologique. À comparer le réseau formé par les coprésences au sein des jurys de soutenance des en soi et pour soi (Graphe 4) et le réseau formé par les coprésences au sein des jurys de soutenance de l'ensemble des communicant·e.s sur l'art et la culture (Graphe 5) ${ }^{35}$, il apparaît en effet que le premier réseau est davantage une version réduite du second qu'une version radicalement différente, qui déformerait significativement la structure du réseau initial.

34 Ce constat rejoint celui d'une sociologie de l'art et de la culture qui, bien qu'institutionnalisée, peine à acquérir une légitimité scientifique, voire est en situation de « relégation scientifique » (Alexandre $2015: 539$ et 542).

35 Afin de rendre ces graphes plus lisibles, les membres de jury n'apparaissant qu'une fois ont été supprimé·e·s et ne participent donc pas à la structuration du réseau. De plus, il faut logiquement faire partie d'un jury d'au moins deux personnes pour être pris.e en compte, ce qui signifie que lorsque seul.e le directeur ou la directrice de thèse est connu.e (notamment pour les doctorantee.s, sauf en codirection), ileelle ne participe pas à la construction du réseau. La taille des nœuds est proportionnelle à leur indice de centralité betweenness. Quant à la couleur des nœuds et des liens, elle dépend de leur classe de modularité. in the academic field ${ }^{33}$, both in terms of gender and of institutional trajectory, and their proximity to artistic and cultural fields and disciplines can be described as a specific capital. Thus, they do appear to belong to a space "which, although hierarchized, offer[s] [an] autonomous hierarch[y]" (Bourdieu 1988: 283). Does this mean there is such a thing as a subfield of sociologists of art and culture in themselves and for themselves?

The study of their PhD examination panels does not allow us to fully validate our initial hypothesis of a genuinely autonomous space. Inspired by Olivier Godechot's research (Godechot 2013), network analysis applied to co-presences in the PhD panels for speakers on art and culture shows that the sociologists of art and culture in themselves and for themselves are in effect not that distinctive within the sociological field. If we compare the network formed by co-presences on the PhD panels of the in themselves and for themselves (Graph 4) and the network formed by co-presences on the PhD panels of all speakers on art and culture (Graph 5) ${ }^{34}$, it appears that the first network is more a smaller version of the second than a radically different one. There would most likely be a much more significant deformation if we compared the network of the PhD panels of speakers on art and culture with the network of all congress speakers that we observe here by simply increasing

33 Likewise, it has been asserted elsewhere that the sociology of art and culture although institutionalized, has been struggling to acquire scientific legitimacy and faces "scientific relegation" (Alexandre 2015: 539 and 542).

34 In order to make these graphs more readable, we excluded panel members with only one appearance; therefore, they do not contribute to structuring the network. Additionally, one obviously needs to be a member of a panel for at least two individuals to be taken into account, meaning that in cases where only the PhD supervisor is known (especially frequent for PhD candidates, except those with two supervisors), they do not contribute to structuring the network. The size of nodes is proportional to their betweenness centrality index. The colours of nodes and ties depend on their modularity class. 


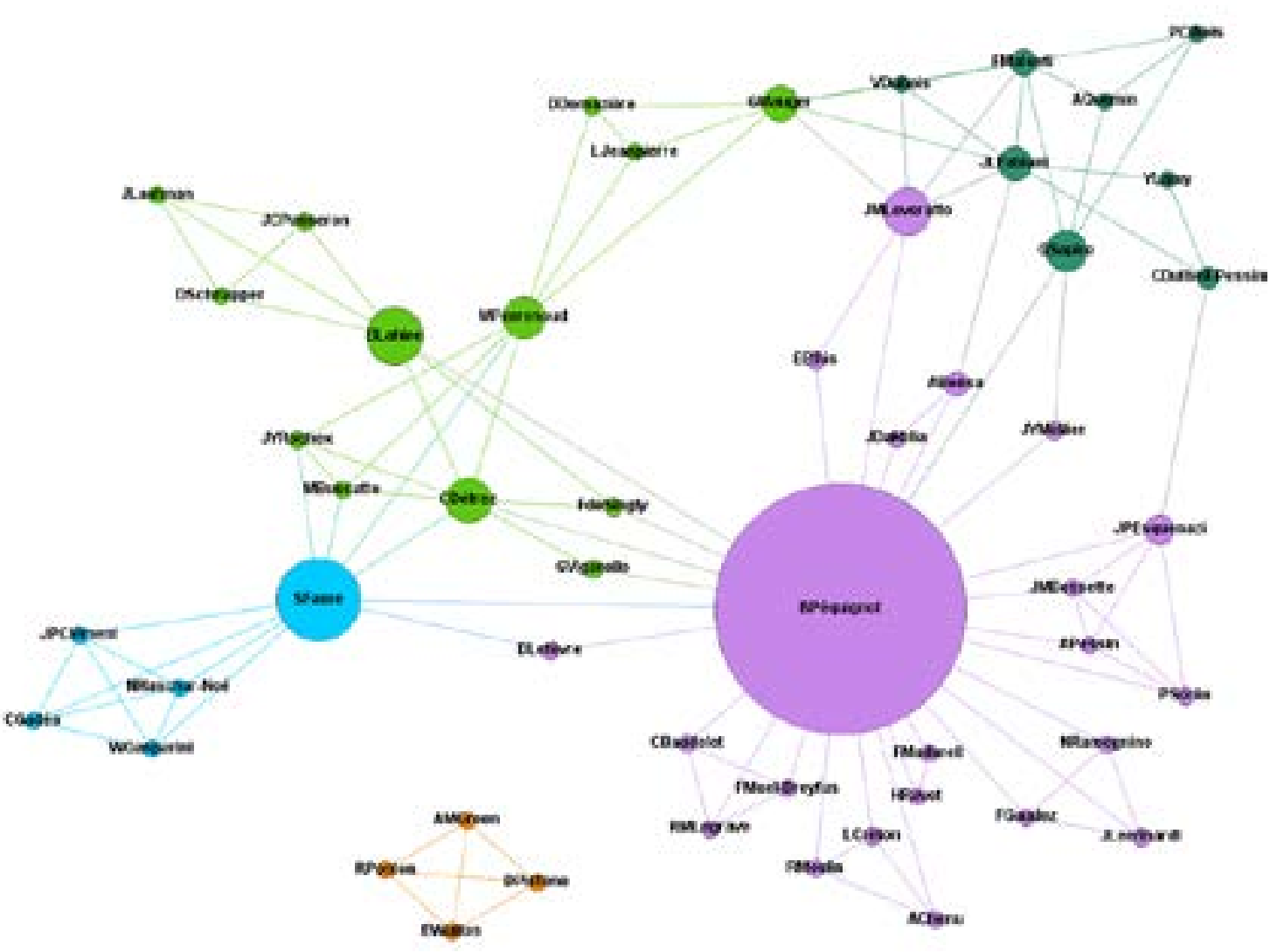

Graphe 4. Réseau des membres de jury de thèse des sociologues de l'art et de la culture en soi et pour soi 36

Graph 4.Network of $\mathrm{PhD}$ examination panel members for sociologists of art and culture in themselves and for themselves ${ }^{35}$

Lecture : Anne-Marie Green se retrouve à plusieurs reprises (et uniquement) aux côtés de Rémy Ponton, de la musicologue Danièle Pistone et du politiste Emmanuel Wallon au sein des jurys de thèse des en soi et pour soi. Ces quatre nœuds forment une classe de modularité (couleur orange) particulièrement nette car Is sont très liés entre eux tout en étant coupés du reste du réseau How to read this graph: Anne-Marie Green sat on several occasions with Rémy Ponton, musicologist Danièle Pistone and political scientist Emmanuel Wallon (and only them) on $\mathrm{PhD}$ panels of the in themselves and for themselves. These four nodes form a particularly distinct modularity class (in orange) because they are closely related to each other and at the same time very far from the rest of the network.

36 Le graphe est construit à partir des jurys de 21 individus et comporte 52 nœuds et 111 liens.

This graph is based on the $\mathrm{PhD}$ examination panels of 21 individuals and features 52 nodes and 111 ties. 

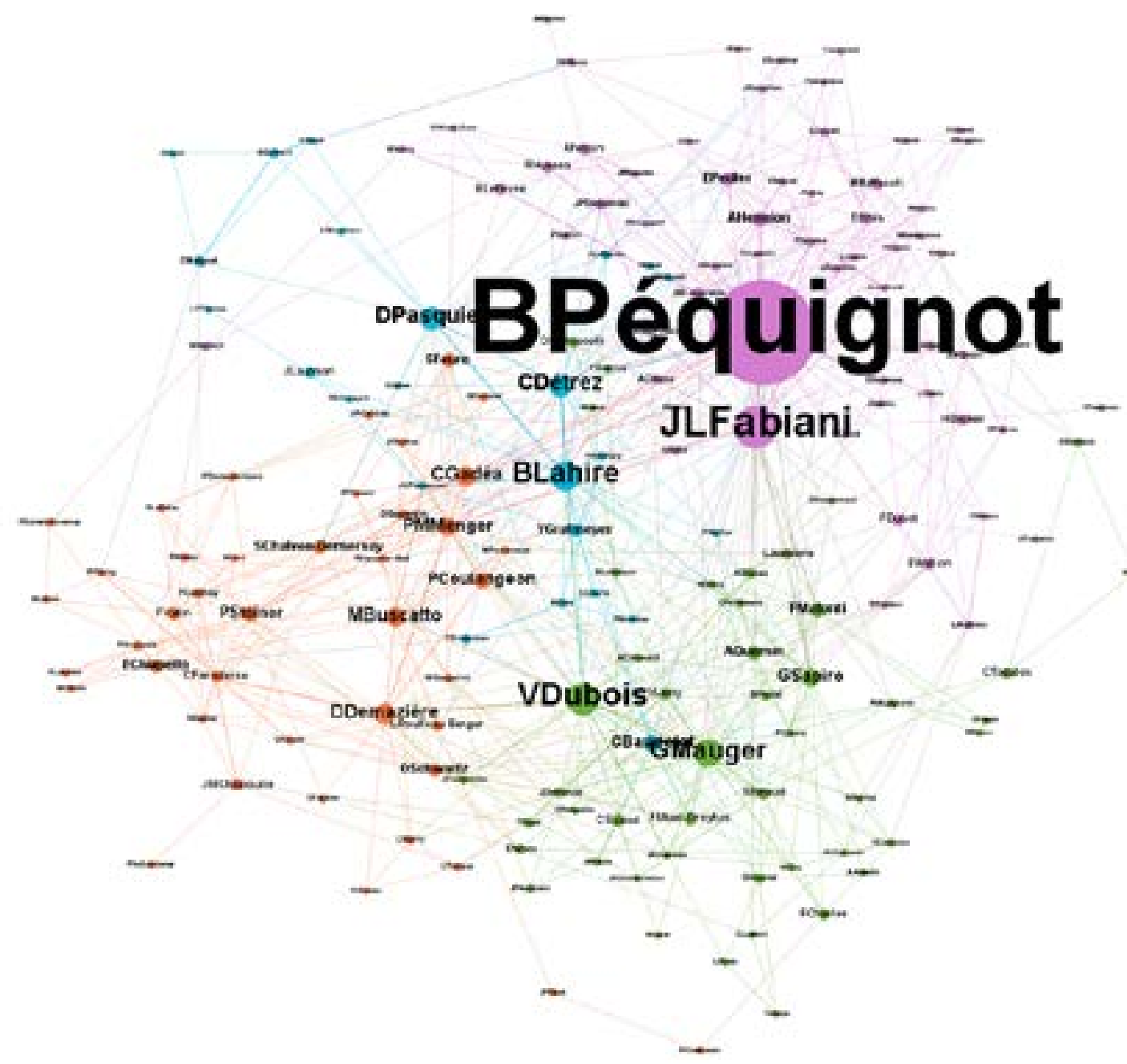

Graphe 5. Réseau des membres de jury

de thèse des communicant.e.s sur l'art et la culture ${ }^{37}$

Graph 5. Network of PhD examination panel members for speakers on art and culture ${ }^{36}$

Lecture : Bruno Péquignot est le nœud le plus central du réseau, car il se retrouve fréquemment aux côtés de membres de jury qui se rencontrent rarement, sinon jamais On le retrouve ainsi aux côtés tantôt de Raymond Boudon, tantôt de Michel Maffesoli, tantôt de Pierre-Michel Menger, tantôt de Bernard Lahire, tantôt de la musicologue Danièle Pistone, etc. C'est néanmoins des membres de jury de sa classe de modularité (couleur violette) dont il est le plus proche, car c'est avec ces membres qu'il partage le plus de liens. How to read this graph: Bruno Péquignot is the most central node in the network, as he frequently sits on examination panels alongside others who are rarely, if ever, together, such as Raymond Boudon, Michel Maffesoli, Pierre-Michel Menger, Bernard Lahire, Danièle Pistone, etc. However, he is closer to the examination panel members in his modularity class (in purple) as he shares the most ties with them.

37 Le graphe est construit à partir des jurys de 162 individus et comporte 176 nœuds et 860 liens.

6 This graph is based on the $\mathrm{PhD}$ examination panels of 162 individuals and features 176 nodes and 860 ties. 
La déformation, si on passait du réseau des jurys de thèse des communicante.e.s sur l'art et la culture à celui de l'ensemble des congressistes, serait sans doute beaucoup plus forte qu'elle ne l'est ici lorsqu'on augmente le degré de spécialisation à l'intérieur même de cette thématique. De plus, si l'espace des sociologues les plus spécialisé·e.s en art et culture était autonome, c'est-à-dire situé dans un endroit particulier du champ académique, le réseau formé par les membres de leurs jurys de thèse serait moins éclaté que celui relatif aux communicant $\cdot e \cdot s$ sur l'art et la culture, et des membres de jury appartenant à une même classe de modularité au sein du réseau global se retrouveraient fréquemment dans des classes distinctes au sein du réseau spécialisé. Or, on constate une grande diversité des positions structurelles (ainsi, on retrouve dans le réseau spécialisé des membres de jury qui apparaissent très éloigné.e.s dans le réseau global, tel·le·s que Anne-Marie Green et Didier Demazière) et une relative inertie des classes de modularité. En outre, les nœuds les plus centraux sont souvent les mêmes (Bruno Péquignot, Bernard Lahire, Christine Détrez, Gérard Mauger, Gisèle Sapiro...), même si on observe certaines variations qui semblent inversement corrélées au capital académique de l'examinateur-rice (ainsi de Pierre-Michel Menger, absent du réseau caractérisant les sociologues spécialisé·e·s, tandis que Sylvia Faure y apparaît centrale) - ce qui constitue un indice de plus de la position relativement dominée de cet espace.

Enfin, l'examen du réseau des membres de jury de thèse des en soi et pour soi conduit à relativiser un constat fait précédemment à propos des liens que ces dernier.e.s entretiennent avec les arts. Ce sont en effet avant tout des sociologues qu'on retrouve dans ce réseau alors qu'on aurait pu penser qu'une forte spécialisation en art et culture s'accompagnerait d'une présence plus importante de représentant $\cdot$ e.s des disciplines artistiques lors des soutenances. En d'autres termes, si la spécialisation traduit des centres d'intérêt qui the degree of specialization in art and culture. Furthermore, if the space of the most specialized sociologists of art and culture were autonomous, i.e., situated at a particular point in the academic field, the network formed by their PhD panel members would be less diverse than the same one pertaining to speakers on art and culture, and panel members belonging to the same modularity class in the global network would frequently end up in distinct classes in the specialist network. In effect, we observe highly varied structural positions (for instance, in the specialist network, we find panel members who are very far apart in the global network, like Anne-Marie Green and Didier Demazière) and a relative inertia of modularity classes. Additionally, the most central nodes are often the same (Bruno Péquignot, Bernard Lahire, Christine Détrez, Gérard Mauger, Gisèle Sapiro, etc.), even if we note some variations that appear to be inversely correlated to the panel member's academic capital (for instance, Pierre-Michel Menger is not in the specialist network, whereas Sylvia Faure has a central place in it)-which further indicates the relatively dominated position of that space.

Lastly, examination of the network of PhD panel members of the in themselves and for themselves suggests that our previous observation regarding their relationships with the arts deserves nuancing. Indeed, we find mostly sociologists in these networks, where we might have assumed that a strong specialization in art and culture would mean more representatives of artistic disciplines on $\mathrm{PhD}$ examination panels. In other words, while specialization reflects areas of interest that show in disciplinary affiliations during 
se donnent à voir également au travers des ancrages disciplinaires lors des études universitaires, elle s'accompagne au contraire d'un recentrement sur la sociologie lorsqu'il s'agit de subir la principale épreuve de certification étatique de son capital académique. Ainsi, la spécialisation en art et culture ne peut pas s'interpréter comme la poursuite d'enjeux autonomes qui caractériserait un espace luimême autonome. Si autonomie il y a, elle n'est que très limitée. Parce que la structuration de cet espace reflète celle du champ sociologique dans son ensemble, il reste difficile, en définitive, de parler de véritable sous-champ de la sociologie.

\section{Conclusion}

La manière la plus courante d'appréhender les différentes thématiques qui coexistent en sociologie semble de les envisager comme des sous-disciplines qui fonctionneraient comme des sous-champs relativement autonomes. Ainsi, pour caractériser la sociologie de l'art et de la culture en France, Olivier Alexandre parle de « sous-discipline » (Alexandre 2015), Bruno Péquignot de "sous-champ disciplinaire " (Péquignot 2005) et Vincent Dubois de " champ de recherche sociologique » (Dubois 2007). De la même manière, pour décrire " la sociologie de la délinquance juvénile », Gérard Mauger parle d'« un sous-champ de la sociologie " (Mauger 2005). Une telle manière de concevoir les divisions intra-disciplinaires n'est pas réservée à la sociologie française : ainsi, pour Étienne Ollion, les sections de l'American Sociological Association, produits du « processus de diversification et de spécialisation » de la sociologie états-unienne, recoupent des «sous-champs thématiques » et « en forment la structure » en même temps qu'elles en « assurent l'existence » (Ollion 2011 : 286-288).

À partir du cas de la spécialité « sociologie de l'art et de la culture » en France, l'objectif de cet article a été d'interroger cette higher education, it leads to a re-centring on sociology at the point when their academic capital is publicly certified. Specialization in art and culture cannot therefore be interpreted as the pursuit of autonomous rewards characterizing an autonomous space. Whatever degree of autonomy there may be here is very limited. As the structure of this space appears to mirror the structure of the sociological field as a whole, it seems ultimately difficult to argue that we are dealing with a genuine subfield of sociology.

\section{Conclusion}

The most common way of addressing the coexisting themes studied in sociology appears to consist in envisioning them as sub-disciplines, functioning as relatively autonomous subfields. For instance, the sociology of art and culture in France has been characterized as a "sub-discipline" by Olivier Alexandre (Alexandre 2015), a "disciplinary subfield" by Bruno Péquignot (Péquignot 2005) and a "field of sociological research" by Vincent Dubois (Dubois 2007). Likewise, Gérard Mauger described the "sociology of juvenile delinquency" as a "subfield of sociology" (Mauger 2005). This conception of intra-disciplinary subdivisions is not the preserve of French sociology: Étienne Ollion noted that the sections of the American Sociological Association, the products of the "process of diversification and specialization" of US sociology, overlap with "thematic subfields" and both "form their structure" and "ensure their existence" (Ollion 2011: 286-288).

In this paper, we have used the case of the speciality called "sociology of art and culture" in France to challenge this common 
manière habituelle de voir la discipline sociologique, en la mettant à l'épreuve plutôt qu'en l'acceptant d'emblée : cette thématique est certes institutionnalisée, notamment via le RT14, mais peut-on pour autant parler de « sous-champ » pour la désigner?

L'analyse des propriétés des communicant·e.s sur l'art et la culture et de leurs circulations entre les différents RT de l'AFS montre tout d'abord que, si sous-champ il y a, ses frontières ne sont assurément pas celles du RT qui en porte le nom. Nos résultats permettent en outre d'établir que l'ensemble des communicant·e.s sur l'art et la culture ne forment pas non plus un sous-champ. Quant aux sociologues de l'art et de la culture en soi et pour soi, leur haut degré de spécialisation objective et subjective ne suffit pas à faire exister un véritable sous-champ. En effet, si ces individus semblent bien avoir des propriétés distinctives, ils ne sont pas toujours très singuliers, notamment au moment de faire certifier leurs capitaux et, donc, de se positionner vis-à-vis des enjeux académiques. De plus, les en soi et les pour soi ne sont pas complètement confondu.e.s : il reste possible d'être objectivement spécialisé·e sans se sentir subjectivement investi·e dans cette activité, décalage en contradiction avec l'idée même d'un sous-champ pleinement constitué

L'institutionnalisation des RT dans le cadre de la sociologie française semble donc, au prisme de la sociologie de l'art et de la culture, avoir des effets paradoxaux : invitant à la spécialisation, favorisant l'autonomie, ces RT sont également des espaces de dialogue, propices à un certain œcuménisme ; ils apparaissent contribuer aussi bien à l'éclatement qu'à la cohésion du champ sociologique. Ainsi, les spécialités ne font pas nécessairement les spécialistes. II resterait toutefois à mener un travail de même type sur d'autres spécialités pour savoir dans quelle mesure nos résultats sont, ou non, généralisables à la sociologie française dans son ensemble perception of the sociological discipline, by putting it to the test rather than accepting it as a given. This theme may admittedly be institutionalized, particularly through RT14, but does that warrant describing it as a "subfield"?

Our analysis of the properties of speakers on art and culture and their circulation between the AFS thematic networks first shows that, if a subfield exists, its boundaries are clearly not the same as those of its namesake RT. Our findings also show that speakers on art and culture as a whole do not form a subfield. When it comes to the sociologists of art and culture in themselves and for themselves, their high degree of objective specialization is not sufficient to bring a genuine subfield into existence. While they appear to have distinctive features, they do not always stand out significantly, particularly when the time comes for them to have their capitals certified and accordingly to position themselves in academia. Furthermore, the in themselves and the for themselves do not entirely overlap: being objectively specialized without feeling subjectively invested in that activity remains possible-a gap that contradicts the very idea of a fully formed subfield.

Based on the case of the sociology of art and culture, the institutionalization of the AFS thematic networks in French sociology appears to have paradoxical effects. Although the networks call for specialization and encourage autonomy, they are also spaces for dialogue that are conducive to openness; they appear to be both a scattering and a cohesive force in the sociological field. Specialities do not necessarily make specialists. Further research will however have to examine other specialities to assess the extent to which these findings apply to French sociology as a whole (we may imagine that some specialities are more specialized than others), in 
(on peut toutefois imaginer que certaines spécialités soient plus spécialisées que d'autres), par opposition peut-être à la sociologie états-unienne, apparemment plus segmentée (Ollion 2011)

En étudiant la sociologie de l'art et de la culture, et puisque nous sommes nous-mêmes impliqué·e·s au moins en partie dans cette spécialité, nous avons entrepris de " pren[dre] pour objet un monde social dans lequel on est pris » (Bourdieu 2012 : 11), et dans lequel la revue-même dans laquelle nous publions est prise. $\mathrm{Ni}$ spécialisée strictement en sociologie de l'art et de la culture, ni tout à fait généraliste, la revue Biens symboliques/Symbolic Goods, en tant que nouvelle institution dans le champ académique, ne sera sans doute pas sans effet sur le degré d'autonomie de cette spécialité. À ce titre, il n'est pas exclu qu'elle constitue un jour un terrain d'enquête complémentaire au travail réalisé ici. possible contrast with the more segmented sociological landscape in the United States (Ollion 2011).

By studying the sociology of art and culture, a speciality in which we are ourselves to some extent active, we chose to "study the social world in which we are involved" (Bourdieu 1988: 1). It is also the world in which the journal that is publishing this article is involved. Being neither strictly specialized in the sociology of art and culture nor generalist, Biens symboliques / Symbolic Goods, as a new institution in the academic field, will most likely have an impact on the degree of autonomy of this speciality - which makes it a potential site of future complementary investigation.

Géraldine Bois Université de Lorraine/Laboratoire Lorrain de Sciences Sociales (2L2S)

Adrien Thibault Université de Strasbourg/Laboratoire Sociétés, acteurs, gouvernement en Europe (Sage) 


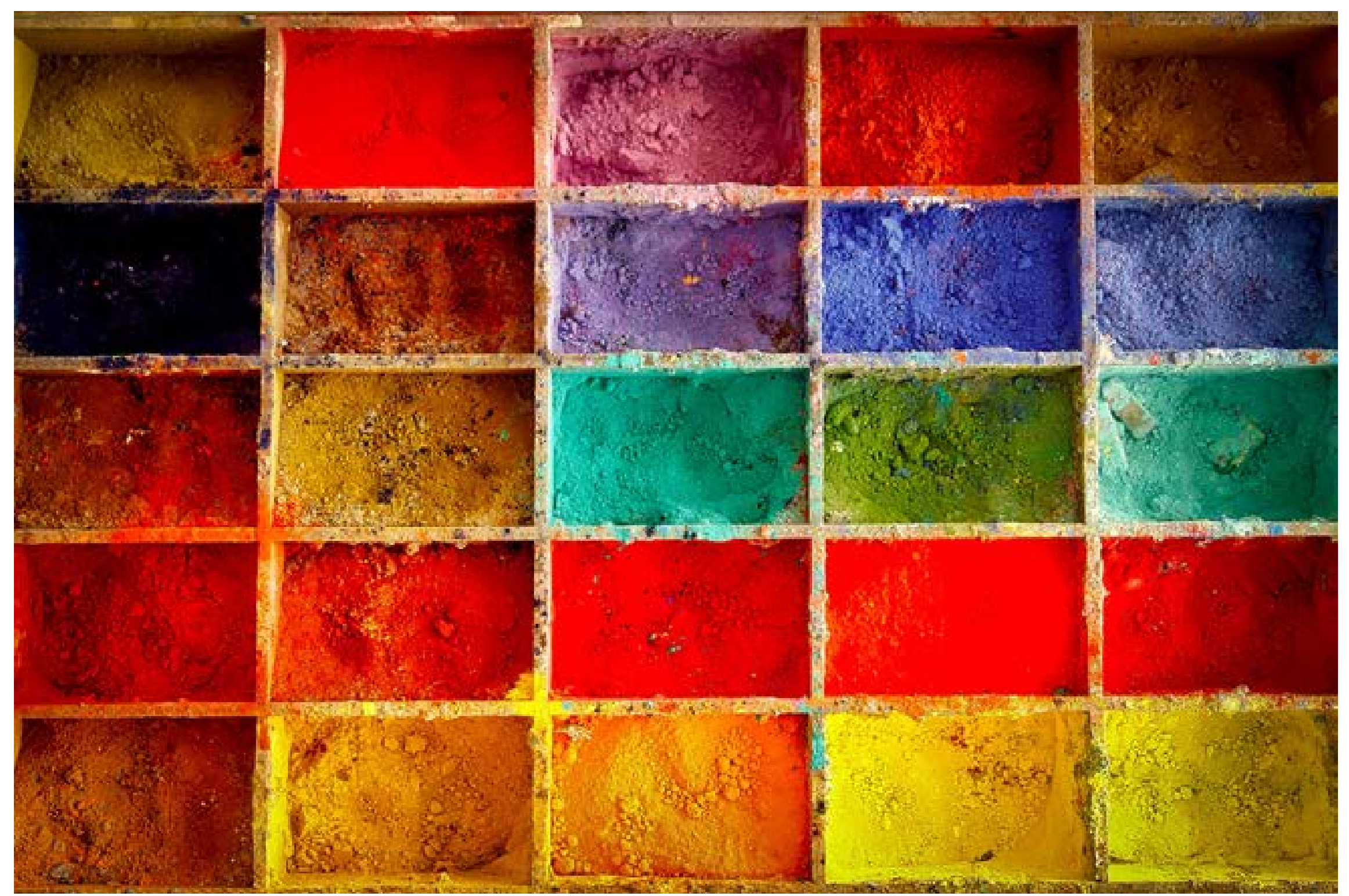

Illustration 2. Transgressions de frontières/Blurring of Boundaries

Source : Fiezfotos, Farbpulver [https://pixabay.com/en/paint-farbpulver-artist-color-2924891/], CCo Creative Commons. 


\section{Références bibliographiques}

AlexANDRE Olivier (2015). « Upside down. Trajectoire croisée de la sociologie de l'art et de la culture ». In Paradeise Catherine, Lorrain Dominique, Demazlère Didier (dir.). Les Sociologies françaises. Héritages et perspectives (1960-2010). Rennes, Presses universitaires de Rennes : 531-544.

ANDREW Edward (1983). "Class in Itself and Class against Capital : Karl Marx and His Classifiers ». Canadian Journal of Political Science/Revue canadienne de science politique, 16(3) : 577-584.

BEAUD Stéphane (2006). «Les angles morts de la sociologie française ». In Beaud Stéphane, ConfaVReuX Joseph, LINDGAARD Jade (dir.). La France invisible. Paris, La Découverte : 459-472.

BOUDESSEUL Gérard (2005). « De quoi parlent les sociologues réunis en congrès ? Éléments de complémentarité entre une analyse lexicale ouverte et le cumul de variables fermées ". Bulletin de méthodologie sociologique, 85 : 68-84.

BOUDESSEUL Gérard (2006). «Brève sociographie du second congrès de l'AFS. Bordeaux septembre 2006 ». Bulletin de méthodologie sociologique, 92. [En ligne] http://bms.revues.org/578 [consulté le 5 décembre 2017].

BOURDiEu Pierre (1976). "Le champ scientifique ». Actes de la recherche en sciences sociales, 2-3 : 88-104.

Bourdieu Pierre (1979). La Distinction. Critique sociale du jugement. Paris, Minuit.

BOURDIEU Pierre (2009) [1981]. «Quelques propriétés des champs ». In BouRdieu Pierre. Questions de sociologie. Paris, Minuit : 113-120.

\section{References}

Alexandre Olivier (2015). "Upside down. Trajectoire croisée de la sociologie de l'art et de la culture." In Paradeise Catherine, LorRain Dominique, DemAZIÈRE Didier (eds.). Les Sociologies françaises. Héritages et perspectives (1960-2010). Rennes, Presses universitaires de Rennes: 531-544.

ANDREW Edward (1983). "Class in Itself and Class against Capital: Kar Marx and His Classifiers." Canadian Journal of Political Science/Revue canadienne de science politique, 16(3): 577-584.

BEAUD Stéphane (2006). "Les angles morts de la sociologie française." In Beaud Stéphane, ConfavreuX Joseph, LindgaARd Jade (eds.). La France invisible. Paris, La Découverte: 459-472.

BOUDESSEUL Gérard (2005). "De quoi parlent les sociologues réunis en congrès? Éléments de complémentarité entre une analyse lexicale ouverte et le cumul de variables fermées." Bulletin de méthodologie sociologique, 85 : 68-84.

BOUDESSEUL Gérard (2006). "Brève sociographie du second congrès de I'AFS. Bordeaux septembre 2006." Bulletin de méthodologie sociologique, 92. [On line] http://bms.revues.org/578 [accessed on 5 december 2017].

Bourdieu Pierre (1976). "Le champ scientifique." Actes de la recherche en sciences sociales, 2-3: 88-104.

BouRdieu Pierre (1984) [1979]. Distinction: A Social Critique of the Judgement of Taste. English translation by Richard Nice. Cambridge, Harvard University Press.

Bourdieu Pierre (1993) [1981]. "Some Properties of Fields." In BourdieU Pierre. Sociology in Question. English translation by Richard Nice. London, SAGE: 72-77. 
BouRdieu Pierre (2012) [1984]. Homo academicus. Paris, Minuit.

BURT Ronald S. (1992). Structural Holes : The Social Structure of Competition. Cambridge et Londres, Harvard University Press.

CAPpell Charles L. \& Guterbock Thomas M. (1992). «Visible Colleges : The Social and Conceptual Structure of Sociology Specialties ». American Sociological Review, 57 : 266-273.

Chauvel Louis (2001). «Le retour des classes sociales ? ». Revue de I'OFCE, 79 : 315-359.

Chenu Alain \& MARTIN Olivier (2016). «Le plafond de verre chez les enseignants-chercheurs en sociologie et démographie ». Travail, genre et sociétés, 36 : 135-156.

DAIPHA Phaedra (2001). « The Intellectual and Social Organization of ASA 1990-1997 : Exploring the Interface between the Discipline of Sociology and Its Practitioners ». The American Sociologist, 32(3) : 73-90.

DENORD François (2003). Genèse et institutionnalisation du néolibéralisme en France (années 1930-années 1950) (Thèse de doctorat en sociologie). Paris, EHESS.

DeshaYeS Jean-Luc (2015). " Le retour des classes est "populaire" à l'Association française de sociologie ». Savoir/Agir, 34 : 45-54.

DuBoIs Vincent (2007). « Culture. Sociologie de la culture », Encyclopædia Universalis. [En ligne] http://www.universalis.fr/encyclopedie/culturesociologie-de-la-culture/ [consulté le 5 décembre 2017].

DURKheIm Émile (2007) [1893]. De la division du travail social. Paris, PUF.
Bourdieu Pierre (1988) [1984]. Homo Academicus. English translation by Peter Collier. Palo Alto, Stanford University Press.

BURT Ronald S. (1992). Structural Holes: The Social Structure of Competition. Cambridge and London, Harvard University Press.

Cappell Charles L. \& Guterbock Thomas M. (1992). "Visible Colleges: The Social and Conceptual Structure of Sociology Specialties." American Sociological Review, 57: 266-273.

Chauvel Louis (2001). "Le retour des classes sociales?." Revue de I'OFCE, 79: 315-359.

CHENU Alain \& MARTIN Olivier (2016). "Le plafond de verre chez les enseignants-chercheurs en sociologie et démographie." Travail, genre et sociétés, 36: 135-156.

DAIPHA Phaedra (2001). "The Intellectual and Social Organization of ASA 1990-1997: Exploring the Interface between the Discipline of Sociology and Its Practitioners." The American Sociologist, 32(3): 73-90.

DENORD François (2003). Genèse et institutionnalisation du néolibéralisme en France (années 1930-années 1950) (PhD dissertation, Sociology). Paris, EHESS.

DeSHAYES Jean-Luc (2015). "Le retour des classes est 'populaire' à l'Association française de sociologie." Savoir/Agir, 34: 45-54.

DuBoIs Vincent (2007). "Culture. Sociologie de la culture », Encyclopædia Universalis. [On line] http://www.universalis.fr/encyclopedie/culturesociologie-de-la-culture/ [accessed on 5 december 2017]

DURKHEIM Émile (1960) [1893]. The Division of Labour in Society. English translation from French by George Simpson. Glencoe, Free Press. 
GoDECHOT Olivier (2013). Réseaux socio-intellectuels et recrutement dans le monde académique (Thèse d'habilitation à diriger des recherches en sociologie). Paris, Sciences Po.

Jacomy Mathieu, Venturini Tommaso, Heymann Sebastien, Bastian Mathieu (2014). « ForceAtlas2, A Continuous Graph Layout Algorithm for Handy Network Visualization ». PLoS One, 9(6) : 1-12.

MARX Karl (1847). Misère de la philosophie. Réponse à La philosophie de la misère de M. Proudhon. Paris/Bruxelles, A. Frank/C. G. Vogler.

MARX Karl (1969) [1852]. Le 18 Brumaire de Louis Bonaparte [« Der 18te Brumaire des Louis Bonaparte ». Die Revolution, 1]. Traduit de l'allemand par Marcel Ollivier (première traduction française par Edouard Fortin Lille, imprimerie ouvrière, 1891). Paris, Éditions sociales.

MAUGER Gérard (2005). «Quelques problèmes posés par une enquête sur un sous-champ de la sociologie : le cas de la sociologie de la délinquance juvénile ». Communication au colloque du RT27. Limoges, 7-8 avril 2005.

MAuger Gérard (dir.) (2006). Droits d'entrée. Modalités et conditions d'accès aux univers artistiques. Paris, Éditions de la Maison des sciences de l'Homme.

MerCKLÉ Pierre (2004). Sociologie des réseaux sociaux. Paris, La Découverte («Repères »).

MoulIN Raymonde (dir.) (1999) [1986]. Sociologie de l'art. Paris, L'Harmattan.

OlLION Étienne (2011). «De la sociologie en Amérique. Éléments pour une sociologie de la sociologie étasunienne contemporaine ». Sociologie 2(3) : 277-294.
GODECHOT Olivier (2013). Réseaux socio-intellectuels et recrutement dans le monde académique (Dissertation habilitation à diriger des recherches, Sociology). Paris, Sciences Po.

Jacomy Mathieu, Venturini Tommaso, Heymann Sebastien, Bastian Mathieu (2014). "ForceAtlas2, A Continuous Graph Layout Algorithm for Handy Network Visualization." PLoS One, 9(6): 1-12.

Marx Karl (1984) [1847]. The Poverty of Philosophy. English translation by the Institute of Marxism Leninism. Moscow, Progress.

MARx Karl (1898) [1852]. The Eighteenth Brumaire of Louis Bonaparte. English translation by Daniel de Leon. New York, International Publishing Company.

MAUGER Gérard (2005). "Quelques problèmes posés par une enquête sur un sous-champ de la sociologie: le cas de la sociologie de la délinquance juvénile." Communication au colloque du RT27. Limoges, 7-8 avril 2005.

MAUger Gérard (ed.) (2006). Droits d'entrée. Modalités et conditions d'accès aux univers artistiques. Paris, Éditions de la Maison des sciences de l'Homme.

Mercklé Pierre (2004). Sociologie des réseaux sociaux. Paris, La Découverte ("Repères").

MouliN Raymonde (ed.) (1999) [1986]. Sociologie de l'art. Paris, L'Harmattan.

OLLION Étienne (2011). "De la sociologie en Amérique. Éléments pour une sociologie de la sociologie étasunienne contemporaine." Sociologie, 2(3): 277-294. 
PÉQUIGnOT Bruno (2005). « La sociologie de l'art et de la culture en France : un état des lieux ». Sociedade e Estado, 20(2) : 303-335.

SAINT LÉGeR Mathilde (DE) \& VAN Meter Karl (2005). « Cartographie du premier congrès de l'AFS avec la méthode des mots associés ». Bulletin de méthodologie sociologique, 85 : 44-67.

SAPIRO Gisèle (2006). « Réseaux, institution(s) et champ ». In MARNEFFE Daphné (DE) \& BENOîT Denis (dir.). Les Réseaux littéraires. Bruxelles, Le Cri : 44-59.

Sofio Séverine (2009). " L'art ne s'apprend pas aux dépens des mœurs ! ». Construction du champ de l'art, genre et professionnalisation des artistes (Thèse de doctorat en sociologie). Paris, EHESS.

SofIO Séverine (2013). « Histoire de la sociologie des arts et de la culture : un portrait de la revue Sociologie de l'Art ». Communication au RT14, Ve Congrès de l'AFS. Nantes, 3 septembre 2013.

TORnY Didier \& TRABAL Patrick (2006). « Le résumé de communication comme objet sociologique. Une analyse thématique, ontologique et littéraire à l'aide du logiciel Prospéro ». In Demazière Didier, Brossaud Claire, Trabal Patrick, VAN METER Karl (dir.). Analyses textuelles en sociologie. Logiciels, méthodes, usages. Rennes, Presses universitaires de Rennes : 23-79.

TRABAL Patrick (2005). « Le logiciel Prospéro à l'épreuve d'un corpus de résumés sociologiques ». Bulletin de méthodologie sociologique, 85 10-43.
PÉQUIGNOT Bruno (2005). "La sociologie de l'art et de la culture en France: un état des lieux." Sociedade e Estado, 20(2): 303-335.

Saint LÉger Mathilde (DE) \& Van Meter Karl (2005). "Cartographie du premier congrès de l'AFS avec la méthode des mots associés." Bulletin de méthodologie sociologique, 85: 44-67.

SAPIRO Gisèle (2006). "Réseaux, institution(s) et champ." In MARNEFFE Daphné (DE) \& BENOîT Denis (eds.). Les Réseaux littéraires. Bruxelles, Le Cri: 44-59.

Sofio Séverine (2009). "L'art ne s'apprend pas aux dépens des mœurs !" Construction du champ de l'art, genre et professionnalisation des artistes (PhD dissertation, Sociology). Paris, EHESS.

SofIO Séverine (2013). "Histoire de la sociologie des arts et de la culture: un portrait de la revue Sociologie de l'Art." Communication presented at RT14, Ve Congrès de l'AFS. Nantes, 3th September 2013.

TORNY Didier \& TRABAL Patrick (2006). "Le résumé de communication comme objet sociologique. Une analyse thématique, ontologique et littéraire à l'aide du logiciel Prospéro." In DemazièRE Didier, Brossaud Claire, Trabal Patrick, VAN Meter Karl (eds.). Analyses textuelles en sociologie. Logiciels, méthodes, usages. Rennes, Presses universitaires de Rennes: 23-79.

TrABAL Patrick (2005). "Le logiciel Prospéro à l'épreuve d'un corpus de résumés sociologiques." Bulletin de méthodologie sociologique, 85 10-43. 